Article

\title{
Piplartine Analogues and Cytotoxic Evaluation against Glioblastoma
}

\author{
Flávio Rogério da Nóbrega ${ }^{1}$, Ozlem Ozdemir ${ }^{2}$ (D), Sheila Cristina S. Nascimento Sousa ${ }^{3}$, \\ Joice Nascimento Barboza ${ }^{1}$, Hasan Turkez ${ }^{2,4}$ and Damião Pergentino de Sousa ${ }^{1, *}$ (D) \\ 1 Laboratory of Pharmaceutical Chemistry, Universidade Federal da Paraíba, João Pessoa 58051-085, Brazil; \\ frnobrega@hotmail.com (F.R.d.N.); joice_nascimentob@hotmail.com (J.N.B.) \\ 2 Department of Molecular Biology and Genetics, Erzurum Technical University, Erzurum 25240, Turkey; \\ ozlem.ozdemir@erzurum.edu.tr (O.O.); hasanturkez@gmail.com (H.T.) \\ 3 Programa de Pós-Graduação em Engenharia Química, Universidade Federal de Sergipe, \\ São Cristóvão 49100-000, Brazil; shcrisnascimento@yahoo.com.br \\ 4 Department of Pharmacy, “G. d'Annunzio" University of Chieti-Pescara, Via dei Vestini 31, \\ 66013 Chieti Scalo, $\mathrm{CH}$, Italy \\ * Correspondence: damiao_desousa@yahoo.com.br; Tel.: +55-83-3216-7347
}

Received: 27 April 2018; Accepted: 14 May 2018; Published: 8 June 2018

\begin{abstract}
Piplartine (1) is an alkamide extracted from plants of the genus Piper which shows several pharmacological properties, including antitumor activity. To improve this activity, a series of analogues based on $\mathbf{1}$ have been synthesized by esterification and amidation using the 3,4,5-trimethoxycinnamic acid-like starting material. During the study, the moieties 3-(3,4,5-trimethoxyphenyl)acrylate and 3-(3,4,5-trimethoxyphenyl)acrylamide were maintained on esters and amides respectively. Meanwhile, functional changes were exploited, and it was revealed that the presence of two aromatic rings in the side-chain was important to improve the cytotoxic activity against the U87MG cell line, such as the compound (E)-benzhydryl 3-(3,4,5-trimethoxyphenyl)acrylate (10), an ester that exhibited strong cytotoxicity and a similar level of potency to that of paclitaxel, a positive control. Compound $\mathbf{1 0}$ had a marked concentration-dependent inhibitory effect on the viability of the U87MG cell line with apoptotic and oxidative processes, showing good potential for altering main molecular pathways to prevent tumor development. Moreover, it has strong bioavailability with non-genotoxic and non-cytotoxic properties on human blood cells. In conclusion, the findings of the present study demonstrated that compound $\mathbf{1 0}$ is a promising agent that may find applications combatting diseases associated with oxidative stress and as a prototype for the development of novel drugs used in the treatment of glioblastoma.
\end{abstract}

Keywords: cancer; cytotoxic activity; antitumor; phenylpropanoid; alkaloid; natural product; esters; oxidative stress; Piper; synthetic derivatives

\section{Introduction}

Glioblastoma (GBM) is the most fatal primary brain cancer found in humans, with about 3 in 100,000 people developing the disease every year [1,2]. It originates from glial cells, but rarely disseminates outside the nervous system and grows diffusely into surrounding brain tissue. This cancer is still incurable and is characterized by nuclear atypia, mitotic activity, intense microvascular proliferation and necrosis. It occurs more frequently in males and there is no association with smoking [3], consumption of cured meat [4] or electromagnetic fields [5], however some viruses such as SV40 and HHV have a positive association [6,7]. Currently treatment for the cancer involves 
a multimodal approach which include surgery (total removal of tumor), post-operative radiation therapy radiotherapy (RT) and concurrent and adjuvant temozolomide (TMZ). The median survival rate is only 14.6 months with less than $3 \%$ to $5 \%$ of sufferers surviving longer than five years. Without treatment, the patient does not survive for more than 3 months [2].

The gliomagenesis occurs with a multistep process that exhibits complex patterns of abnormal gene expression [8]. The primary GBMs exhibit epidermal growth factor receptor (EGFR) amplification, phosphatase and tensin homolog (PTEN) mutation as well as the loss of chromosome 10. The secondary GBMs exhibit p53 mutation. And, glioblastoma tumor growth has been found as suppressed via $A K T$-mediated inhibition [9]. The ligation of EGFR by epidermal growth factor (EGF) induces endogenous generation of intracellular ROS and $\mathrm{H}_{2} \mathrm{O}_{2}$ in the cancer cell line. It is also clear that PIP3K/AKT pathways play an important role in the regulation of metabolism, apoptosis and survival in normal cells [10].

Piplartine (1) is an alkamide commonly found in long pepper (Piper longum L.). Previous reports indicated piplartine exhibited a wide range of pharmacological activities, including anti-diabetic, anti-ulcer, anti-platelet aggregation, anti-atherosclerotic, anti-depressant, anti-bacterial and anti-fungal properties [11-14]. Moreover, this compound possesses a highly selective and effective antitumor property, which protects against various types of tumors $[15,16]$. It has recently been demonstrated that piplartine kills HGG (high-grade glioma) cells by PRDX4 inactivation inducing endoplasmic reticulum stress [10]. Therefore, the antitumor activity of piplartine (1) in a type of cancer of the Central Nervous System motivated us to investigate a collection of synthetic analogues of piplartine on human U87MG glioblastoma cell line, as well as exploring the molecular genetic basis underlying their effects for the first time.

\section{Results}

\section{Chemistry}

For this study, 18 analogues of $\mathbf{1}$ (Figure 1) were synthesized, maintaining the similar moiety (E)-3-(3,4,5-trimethoxyphenyl)acryloyl in the esters and amides (Scheme 1). Side-chain modifications were also evaluated by changing the radical (R) to: methyl (2), ethyl (3), propyl (4), butyl (5), pentyl (6), decyl (7), 2-methoxyethyl (8), iPr (9), $\mathrm{CHPh}_{2}$ (10), carvacryl (11), phenethyl (12), 4-methylphenethyl (13) on esters and butyl (14), benzyl (15), 4-methylbenzyl (16), 4-methoxylbenzyl (17), 4-chlorobenzyl (18) and $N, N$-diethyl (19) on amides. Side-chain modifications are expected to increase lipophilicity and antitumor efficacy of the esters and amides, as well as their mode of interaction with the receptor (Scheme 1) [17-19].

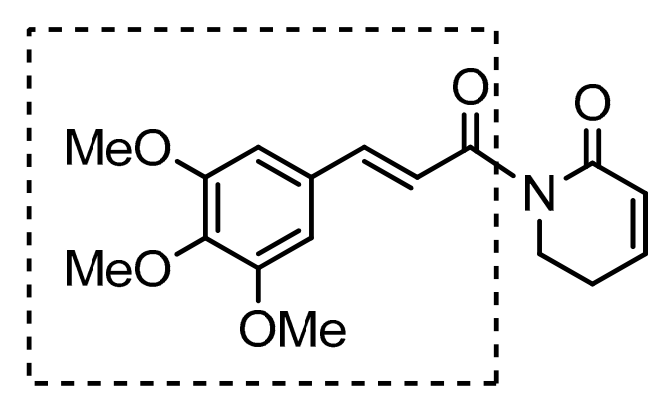

Figure 1. Chemical structure of piplartine (1).

To synthesize the compounds, it starting materials were utilized like 3,4,5-trimethoxycinnamic acid, $\mathrm{ROH}$ to esters and primary or secondary amines to amides. The reactions used were (a), (b), (c) to synthesize esters and (d) to synthesize amides (Scheme 1). Reactions were performed in one step and most products were obtained in high yield. 


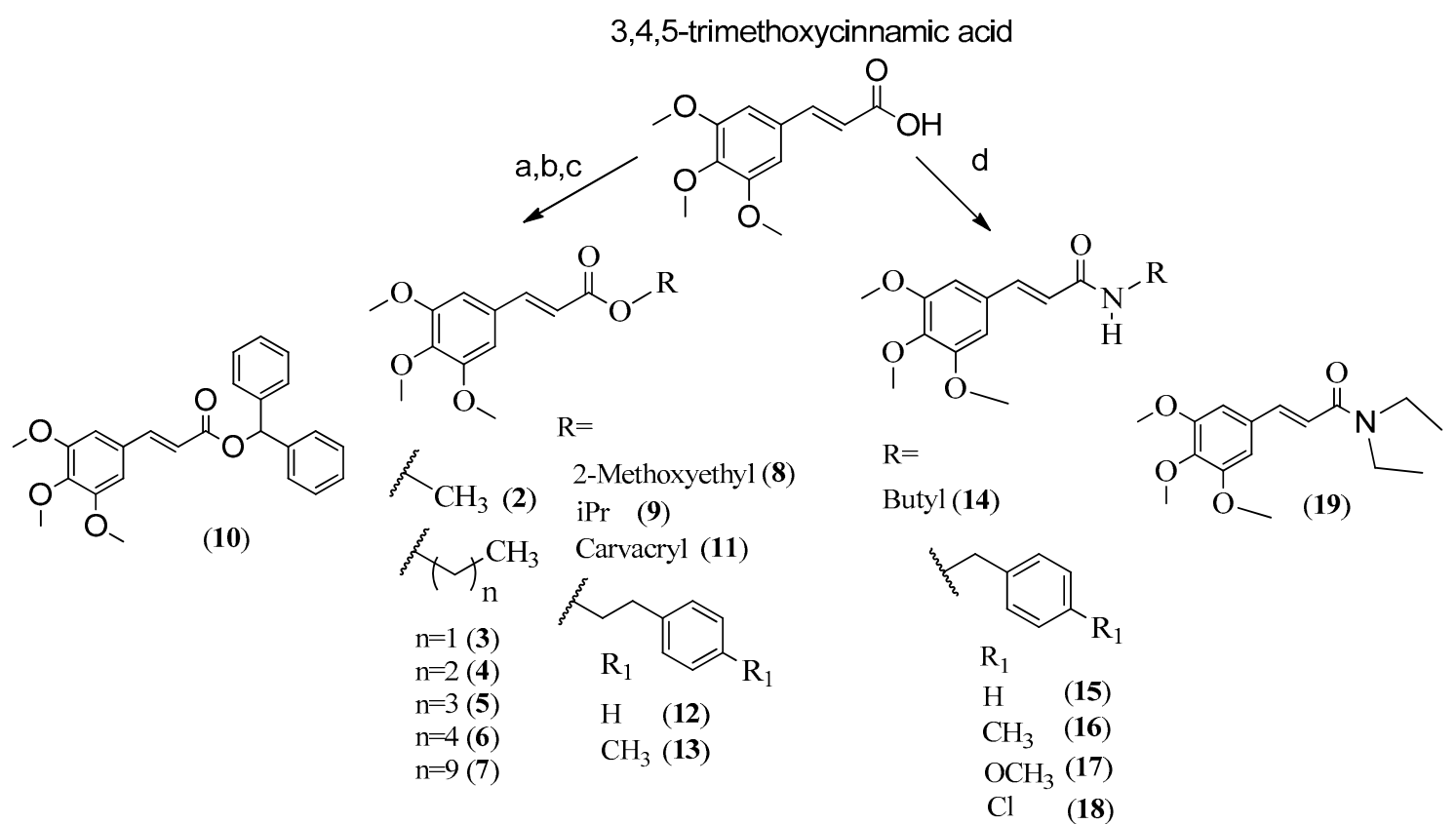

Scheme 1. Reagents and conditions: (a) $\mathrm{ROH}, \mathrm{H}_{2} \mathrm{SO}_{4}$, reflux; (b) $\mathrm{Et}_{3} \mathrm{~N}, \mathrm{RBr}$ or $\mathrm{RCl}$, acetone, reflux; (c) $\mathrm{SOCl}_{2}$, reflux, $\mathrm{ROH}$ (d) $\mathrm{RNH}_{2}$ or $\left(\mathrm{CH}_{3} \mathrm{CH}_{2}\right)_{2} \mathrm{NH}, \mathrm{BOP}, \mathrm{Et}_{3} \mathrm{~N}, \mathrm{CH}_{2} \mathrm{Cl}_{2}, \mathrm{DMF}$.

To evaluate the cytotoxic potential of compounds 2-19 against human U87MG, glioblastoma cells were used with several concentrations ( 0 to $50 \mu \mathrm{g} / \mathrm{mL}$ ). After $48 \mathrm{~h}$ of incubation, cell viability rates were established by MTT and LDH analysis. IC $_{50}$ values of each analogue were determined due to observed cell viability results after MTT assay. All tested analogues led to inhibition of cellular proliferation rates as compared to untreated cells in a clear concentration and compound type dependent manners, as illustrated in Table 1 and Figure 2. In this sense, the most potent cytotoxic agent among those tested was the compound $\mathbf{1 0}$ against U87MG cells.

Table 1. Cytotoxic activity of the compounds $\mathbf{2 - 1 9}$ against proliferation of U87MG cells.

\begin{tabular}{cccc}
\hline \multicolumn{2}{c}{ Esters } & \multicolumn{2}{c}{ Amides } \\
\hline Compound & IC $_{\mathbf{5 0}}(\boldsymbol{\mu} / \mathbf{m L})$ & Compound & IC $_{\mathbf{5 0}}(\mu \mathrm{g} / \mathbf{m L})$ \\
\hline $\mathbf{2}$ & $85.129 \pm 0.78$ & $\mathbf{1 4}$ & $13.196 \pm 0.32$ \\
$\mathbf{3}$ & $100.030 \pm 1.12$ & $\mathbf{1 5}$ & $33.128 \pm 0.41$ \\
$\mathbf{4}$ & $78.393 \pm 0.69$ & $\mathbf{1 6}$ & $22.741 \pm 0.34$ \\
$\mathbf{5}$ & $57.871 \pm 0.71$ & $\mathbf{1 7}$ & $22.654 \pm 0.39$ \\
$\mathbf{6}$ & $31.666 \pm 0.48$ & $\mathbf{1 8}$ & $43.396 \pm 0.48$ \\
$\mathbf{7}$ & $34.926 \pm 0.54$ & $\mathbf{1 9}$ & $36.072 \pm 0.44$ \\
$\mathbf{8}$ & $50.077 \pm 0.62$ & & \\
$\mathbf{9}$ & $81.433 \pm 0.55$ & & \\
$\mathbf{1 0}$ & $2.579 \pm 0.35$ & & \\
$\mathbf{1 1}$ & $26.701 \pm 0.47$ & & \\
$\mathbf{1 2}$ & $24.786 \pm 0.37$ & & \\
$\mathbf{1 3}$ & $30.336 \pm 0.35$ & & \\
\hline
\end{tabular}

Cell apoptosis induced by compound 10 was examined by Hoechst 33,258 staining and observed under a fluorescence microscope at $400 \times$ magnification. U87MG cells were treated with compound 10 for $48 \mathrm{~h}$ at their $\mathrm{IC}_{50}$ concentrations. The nuclear fragmentation of treated cells was compared with the control group and characteristic alterations of apoptosis including enhanced chromatin condensation and nuclear fragmentation were detected in the compound $\mathbf{1 0}$ treated cells (Figure 3). 


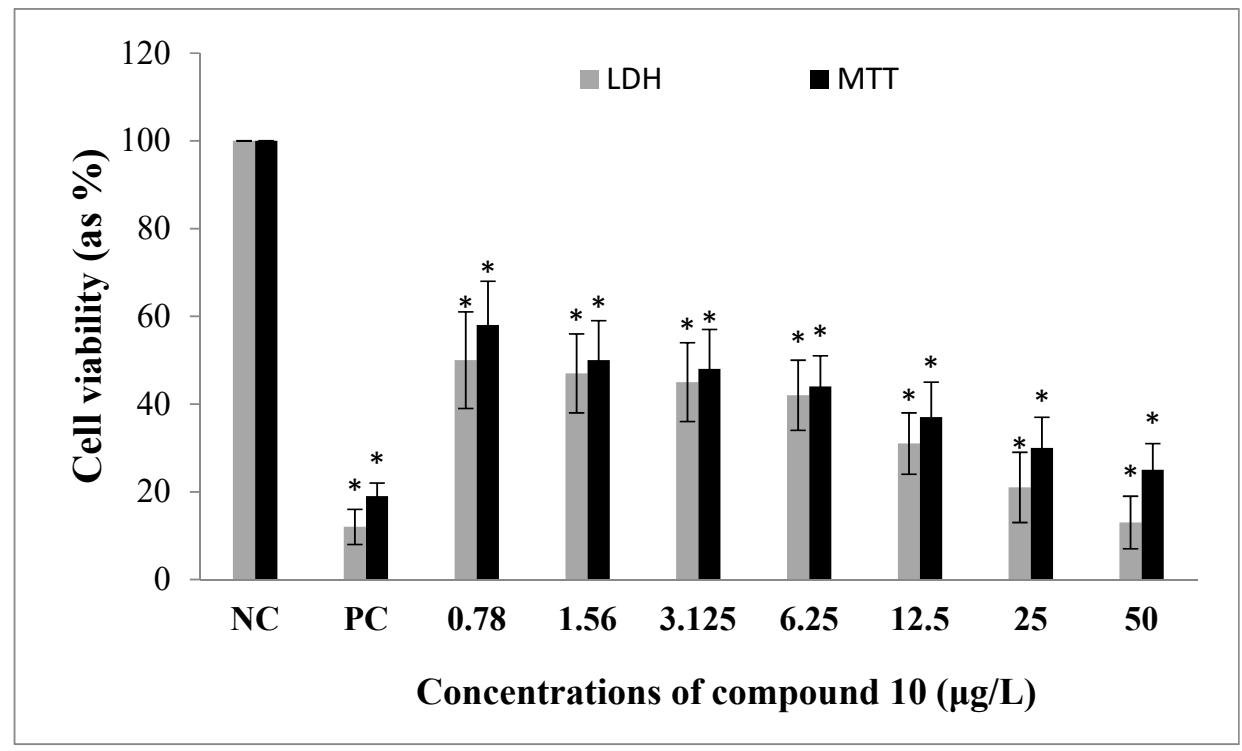

Figure 2. The in vitro effects of compound $\mathbf{1 0}$ on the cell viability of human U87MG glioblastoma cell line. Data are presented as the mean \pm S.D. of four independent experiments. NC: Negative control, PC: Positive control (as paclitaxel). ${ }^{*} p<0.05$, comparison to the NC.
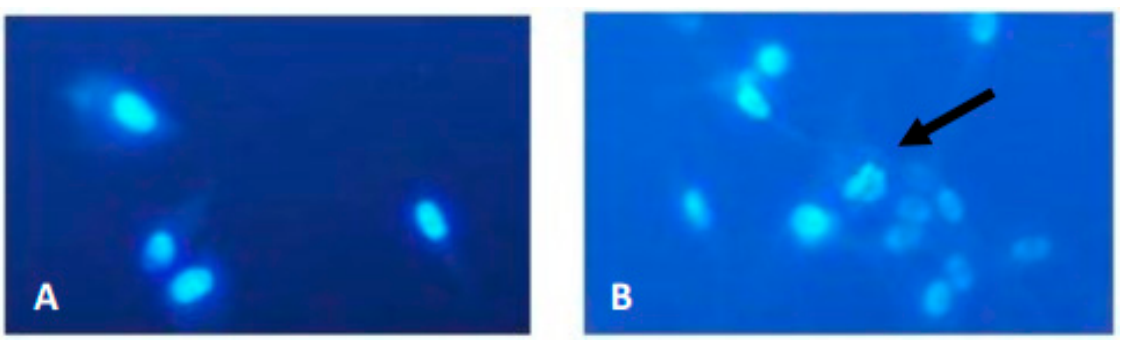

Figure 3. Hoechst 33,258 staining in U87MG cells. (A) Negative control; (B) Cells treated with compound 10 for $48 \mathrm{~h}$ at $\mathrm{IC}_{50}$ concentration (arrow shows nuclear fragmentation, magnification $\times 400$ ).

The total antioxidant capacity (TAC) and the total oxidant status (TOS) levels were evaluated in samples from treated and untreated cultures using colorimetric measurement methods. As shown from the results presented in Figure 4, concentrations $(0.78$ and $50 \mu \mathrm{g} / \mathrm{mL}$ ) of compound 10 resulted in a significant increase of TAC levels on U87MG cells compared with the controls. On the other hand, treatments with compound $\mathbf{1 0}$ did not change the TOS levels in cultured U87MG cells for all the concentrations (data not shown).

To find out the differences in the level of gene expression in U87MG cells exposed using compound 10, a custom plate with 15 different genes involved in cancer related pathways was used via qRT-PCR studies. According to the gene expression results, two genes (AKT1 and AKT2) were significantly ( $>0.5$ fold change) down-regulated and four genes (NF- $k B 1, N F-k B 2, P T E N$ and TP53) were up-regulated in the U87MG cells as compared to untreated subjects upon exposure to 10. However, there were slight and insignificant alterations ( $<0.5$ fold change) of nine genes, including BRAF, DVL1, EGFR, FOS, KRAS, NF-kB1A, RAF1, PIK3CA and PIK3R1 (Figure 5).

To evaluate biosafety of $\mathbf{1 0}$, its cytotoxic and genotoxic potential were investigated on cultured peripheral human whole blood (PHWB) cells. Firstly, the cytotoxicity testing was performed by MTT and LDH assays. The human blood cells exposed to 0.78 to $50 \mu \mathrm{g} / \mathrm{mL}$ of 10 . The results of both assays showed that 10 did not lead to any significant $(p>0.05)$ changes in cell proliferation. Afterwards, genotoxic potential was assessed by SCE testing and determination of 8-OH-dG. There were not significant differences in the frequencies of SCEs between the control group and $\mathbf{1 0}$ treated groups for 
$72 \mathrm{~h}(p>0.05)$. Likewise, 8-OH-dG levels were not increased in the blood cells that were treated with 10 concentrations (Data not shown). Collectively, the 10 exhibited non-cytotoxic and non-genotoxic properties in PHWB cell cultures.

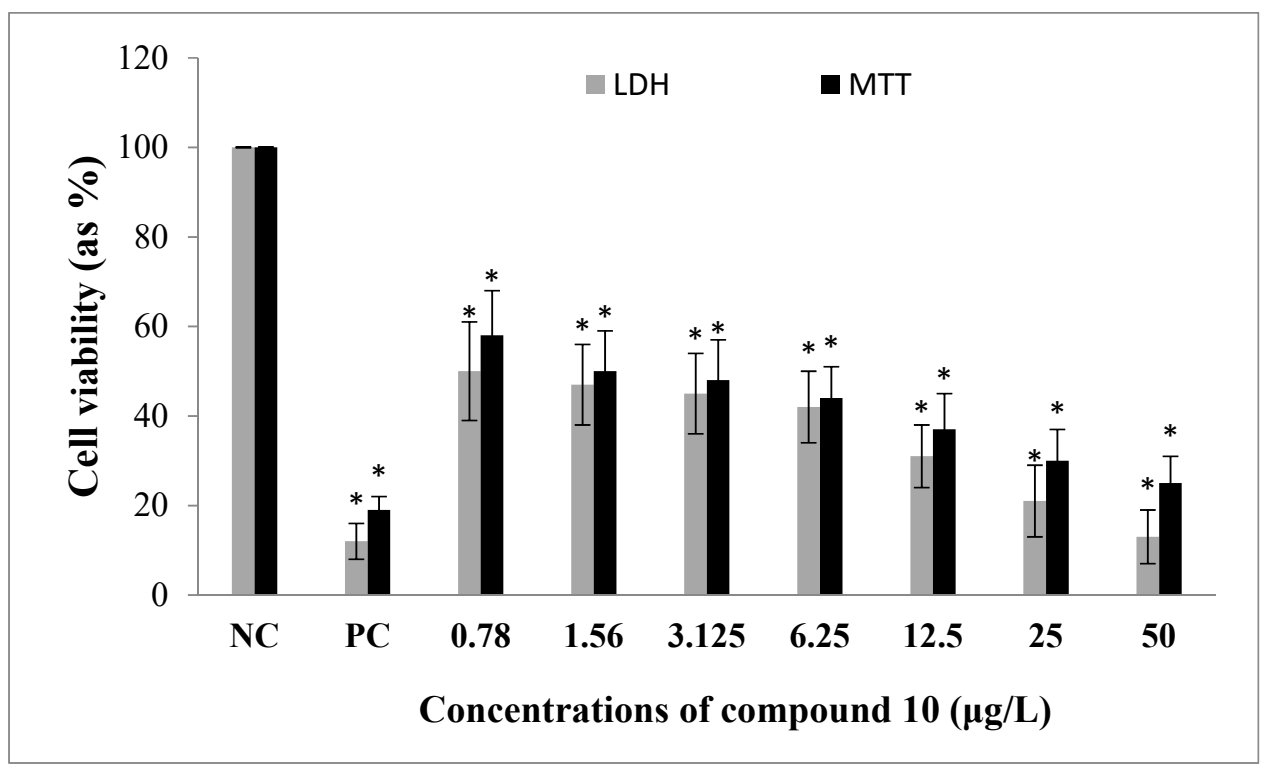

Figure 4. The effects of compound 10 on total antioxidant capacity (TAC) levels in cultured U87MG cells for $48 \mathrm{~h}$. Data are expressed as the mean \pm S.D. of four independent experiments. NC: Negative control, PC: Positive control (as ascorbic acid, $10 \mu \mathrm{M}$ ). ${ }^{*} p<0.05$, comparison to NC.

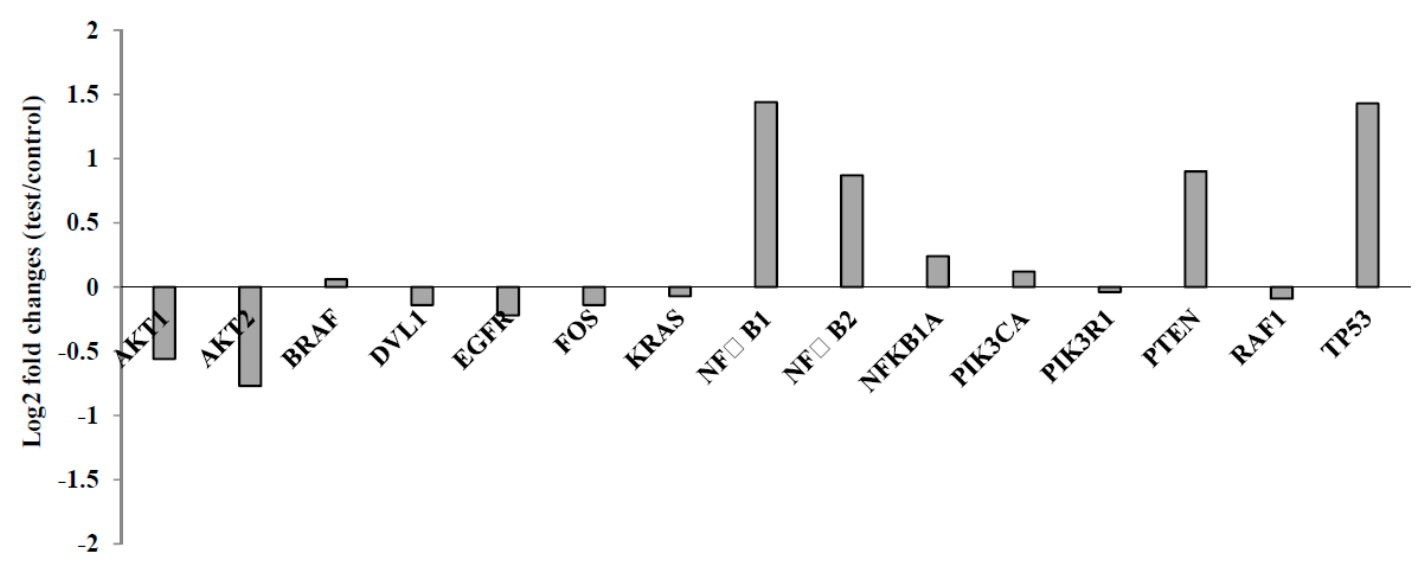

Figure 5. Gene expression alterations after treatment with compound 10 on U87MG cells for $48 \mathrm{~h}$.

\section{Discussion}

\subsection{Structure Activity Relationship (SAR)}

Table 1 shows that the introduction of methylene groups into the radicals attached to the (E)-3-(3,4,5-trimethoxyphenyl)acrylate in compounds $\mathbf{2}-\mathbf{6}$ provided $\mathrm{IC}_{50}$ values inversely proportional to the carbon chain size, with the exception of $3\left(\mathrm{IC}_{50}: 100.030 \pm 1.12 \mu \mathrm{g} / \mathrm{mL}\right)$. Comparing ester 5 (IC ${ }_{50}: 57.871 \pm 0.71 \mu \mathrm{g} / \mathrm{mL}$ ) with amide 14 ( $\mathrm{IC}_{50}: 13.196 \pm 0.32 \mu \mathrm{g} / \mathrm{mL}$ ), it was observed that the butyl radical attached to the group 3,4,5-trimethoxycinnamoyl on amide might more effective than the same radical attached to the group (E)-3-(3,4,5-trimethoxyphenyl)-acrylate on esters. The introduction of methyl groups contributed to increase lipophilicity, but did not show an increase of cytotoxic activity when the compound $12\left(\mathrm{IC}_{50}: 24.786 \pm 0.37\right)$ was compared with $13\left(\mathrm{IC}_{50}: 30.336 \pm 0.35\right)$ [20]. 
For research carried out by Example [21], piplartine (1) and other compounds were isolated from the Piper cernuum plant and the pharmacological activity was made in several tumor cell lines. The cell lines evaluated by the MTT test were: BF16F10-Nex2 (murine melanoma), U87MG (human glioblastoma), HeLa (human cervical carcinoma), HCT (human colon carcinoma), HL-60 (human leukemic cell) and A2258 (human melanoma). The same author showed that 1 did not obtain significant results against these cancer cell lines ( $\mathrm{IC}_{50}:>200 \mu \mathrm{g} / \mathrm{mL}$ in all tested strains), but that one of the analogues, known as piplaroxide, did obtain moderate activity in the BF16F10-Nex2, HeLa and HL-60 strains. Piplaroxide differs from 1 by replacing the double bond between the $5^{\prime}$ and $6^{\prime}$ carbons by an epoxide and absence of the methoxyl at the 3-position of the ring.

The difference in chemical structure of $\mathbf{1}$ and piplaroxide is the oxygen atoms in the portion of the epoxide at the $5^{\prime}$ and $6^{\prime}$ carbons on piplaroxide. This oxygen may have contributed to increased piplaroxide antitumor activity as compared to $\mathbf{1}$ [21,22].

Comparing the side-chains $\mathrm{R}$ of compound $8\left(\mathrm{IC}_{50}: 50.077 \pm 0.62 \mu \mathrm{g} / \mathrm{mL}\right)$ and $4\left(\mathrm{IC}_{50}\right.$ : $78.393 \pm 0.69 \mu \mathrm{g} / \mathrm{mL}$ ), it was found that oxygen is also determinant to increase antitumor activity in the U87MG cell line. In accordance with the current research, the oxygen at the moieties provides a new center for H-bond that could influence the binding of the analogue to its target site [20]. However, the presence of the oxygen on methoxyl moiety on the para position on $\mathrm{R}_{1}$ of amide $\mathbf{1 7}$ ( $\mathrm{IC}_{50}: 22.654 \pm 0.39$ ) did not contribute to improve cytotoxic activity when compared to amide 16 ( $\mathrm{IC}_{50}: 22.741 \pm 0.34$ ), with the presence of the methyl group in this position of the ring.

In general, the presence of aromatic rings on side-chain $\mathrm{R}$ of the esters and amides increased antitumor activities against U87MG, but the trisubstituted aromatic ring present in the carvacryl moiety of ester $\mathbf{1 2}$ did not provide more effectiveness in comparison to the other compounds with aromatic rings on $\mathrm{R}$.

The branch present on side-chains $\mathrm{R}$ of ester $9\left(\mathrm{IC}_{50}: 81.433 \pm 0.55\right)$ did not increase cytotoxic activity compared with other compounds with side-chains $\mathrm{R}$ composed with saturated radicals. However, the change of methyl groups to phenyl on branch radical of ester $10\left(\mathrm{CI}_{50}: 2.579 \pm 0.35\right)$ provide an $\mathrm{IC}_{50}$ more closely to a positive control paclitaxel $\left(\mathrm{IC}_{50}: 2.119 \pm 0.35\right)$ and also appeared to be the most active synthesized compound against the U87MG cell proliferation. Therefore, further experiments were performed with this compound.

\subsection{Biological Activity}

In cell biology, U87MG—an abbreviation for "Uppsala 87 Malignant Glioma" - is a primary lineage of glioblastoma, which, immortalized, originated from a 44-year-old cancer patient. This cell line is usually used to evaluate cytotoxic and genotoxic aspects of drugs and other molecules in brain cancer cells, especially glioblastomas [23]. Present data revealed that tested analogues exhibited anti-proliferative activity. Our findings also showed that compound 10 induced apoptosis in U87MG cells via leading increases of chromatin condensation and nuclear fragmentation. There is scarce data on the anti-glioblastoma actions of 2-19. However, the cytotoxic activities of $\mathbf{1}$ are associated with the generation of ROS, and previous studies have demonstrated that 1 exhibited antiproliferative action via leading decreases of the expression of some key proteins (HER, JAK 1 and 2, STAT3, c-MET, GSTP1, JNK) that are responsible for the development of various cancer types [24-26]. Again, in a current investigation, it was determined that $\mathbf{1}$ served as a microtubule-destabilising agent in MCF-7 breast cancer cells [27]. And, the apoptotic action by 1 was associated to caspase-3-mediated poly (ADP-ribose) polymerase (PARP) cleavage and cell cycle arrest at G2/M phase in cultured human PC-3 prostate cancer cells [28].

Previous research revealed that 1 caused increases of intracellular level of reactive oxidative species (ROS) and inhibited tumor growth [11]. Disparately, present results indicated that oxidative alterations are not closely related to antitumor action by the novel and effective analogue, $\mathbf{1 0}$. In supporting our novel finding on in vitro oxidative effects of $\mathbf{1 0}$ analogue, it was determined that most glioblastomas overexpressed ROS-degrading enzyme peroxiredoxin 4 (PRDX4) and suggested 
that pharmaceutical PRDX4 inactivation effectively kills the cancer cells by increasing ROS levels [10]. Therefore, it can be concluded that analogue $\mathbf{1 0}$ induced oxidative stress that was restored by overexpressed PRDX4 in cultured U87MG cells. Due to this, 1 was found to be less effective in SF-295 human glioblastoma cells as compared to HCT-8 human colon carcinoma cells [29].

Our results firstly revealed that 10 led to down-regulation of $A K T 1$ and AKT2 genes in U87MG cells. Therefore, it was determined that the anticancer potential of $\mathbf{1 0}$ was largely associated with the PI3K/AKT/mTOR pathway, since AKT was an important mediator of this intracellular signaling pathway which is important in cell cycle regulation [30]. PI3K/AKT/mTOR was reported to play key functions on tumor initiation and progression as well as angiogenesis. AKT2 was found to be especially necessary for glioma cell migration [31]. In fact, the enhanced expression of AKT1 and cyclin D1 were detected in cultured U87MG cells [32]. Likewise, AKT1 and AKT2 found to be related to bcatenin/Tcf-4 signaling pathway that promoted malignant transformation in human LN229 glioma cell line. Moreover, AKT1 was considered to be more effective than AKT2 in malignant transformation. Thus, AKT1 and AKT2 were considered as valuable targets for glioblastoma therapy as well as a rational strategy for restraining the metastasis of gliomas [33]. Our positive control agent paclitaxel was known to down-regulate the MMP-9-mediated p38/JNK signaling pathway and block the proliferation of U87MG cells [34]. However, it was determined that the combined use of paclitaxel with alkylating agents supported a greater clinical efficacy of paclitaxel against malignant brain tumors [35]. But the adverse effects of these combinations are still perturbative. At this point, present findings show that 10 as anti-tumoral agent or suppressor with a good biosafety level is interrelated to proliferation and invasion of glioblastoma cells by inhibiting AKT1 signaling and $\mathbf{1 0}$ may be considered as an effective therapeutic treatment against glioblastoma.

The present qRT-PCR analysis revealed up-regulation of the genes involving NF-kB1, NF-kB2, PTEN and TP53 in vitro. Conversely, constitutive activation of NF-KB supported growth and survival of glioblastoma cells in human and mouse models [36]. However, it was determined that varied levels of NF- $\mathrm{KB}$ activation effected cancer propagation via several mechanisms. Thereof, it was considered that the alterations of the NF- $\mathrm{KB}$ signalling response in both upstream stimuli and the downstream targets would be fundamental for gliomagenesis in the near future [37]. Similarly, the overexpression of p53 and mutation in TP53 were associated with adverse outcomes in studies of malignant gliomas from children [38]. On the other hand, the tumor suppressor gene PTEN was shown to regulate Akt signalling, cellular growth and apoptosis [39]. Again, blocking the PTEN expression was linked to metastasis in addition to both radio- and chemotherapy responses in patents with glioma and breast cancer. Accordingly, PTEN is addressed as a main regulator of tumor sensitivity towards different therapeutic options [40-47]. In a recent study [47], it was revealed that PTEN was not the primary target of paclitaxel resistance and its regulator was evaluated as a substantive target for suppression of miR-22, cyclin B1 or combining with inhibitor of Akt, providing a successful strategy for paclitaxel therapy. In this regard $\mathbf{1 0}$ provides a rationale strategy against glioblastoma in single or combined use with other antineoplastic agents. Supplementary materials are available on line.

The human lymphocytes were suggested as a serviceable experimental model for planning chemotherapeutic strategies as well as dose selection from the point of genotoxic and cytotoxic damage potentials of drug/drug candidates on healthy cells [48,49]. Consequently, cultured peripheral human whole blood cells were used to evaluate the cytotoxic (MTT and LDH assays) and genotoxic (SCE and 8-OH-dG assays) potential of $\mathbf{1 0}$. Finally, the property of $\mathbf{1 0}$ as a non-cytotoxic and non-genotoxic agent with high anti-cancer efficacy makes it a potential candidate for novel cancer therapy.

\section{Materials and Methods}

The ${ }^{1} \mathrm{H}$ and ${ }^{13} \mathrm{C}$ NMR, and IR signals assigned to analogues of $\mathbf{1}$ were comparing with signals already published. The unpublished molecules such as 6, 7, 8, 10, 13 and 16 besides the same spectrophotometric methods used to other analogues, was used LS-MALDI TOF/TOF to confirm the synthesis. 
All reagents were purchased from Aldrich and were of commercial grade. IR spectra were recorded on Irprestige-21 Shimadzu Fourier Transform spectrophotometer (Shimadzu, Kyoto, Japan). ${ }^{1} \mathrm{H}$ and ${ }^{13} \mathrm{C}$ NMR spectra were recorded on a Varian Mercury spectrometer $200 \mathrm{MHz}\left({ }^{1} \mathrm{H}\right)$ and $50 \mathrm{MHz}$ $\left({ }^{13} \mathrm{C}\right)$, Varian (Palo Alto, CA, USA). Chemical shifts are reported relative to the solvent peak $\mathrm{CDCl}_{3}$ or TMS. To HMRS was used the equipment ultraflex II MALDI TOF/TOF equipped with a Laser with High Performance $(\lambda=355 \mathrm{~nm}$ ) and reflector operating by software FlexControl 2,4 (Bruker Daltonics $\mathrm{G}, \mathrm{bsH}$, Bremen, Germany) Melting points were measured on an equipment Tecnal PFM-II, 220 V.

\subsection{General Procedure for Synthesis of Compounds 2-5, 8 and $\mathbf{9}$}

To a solution of 3,4,5-trimethoxycinnamic acid $(0.25 \mathrm{~g})$ in $250 \mathrm{~mL}$ of $\mathrm{ROH}, 0.5 \mathrm{~mL} 96 \%(v / v) \mathrm{H}_{2} \mathrm{SO}_{4}$ was added under stirring. The reaction mixture was refluxed for $3 \mathrm{~h}$. Half of $\mathrm{ROH}$ was removed under reduced pressure and the following solution was then diluted with $10 \mathrm{~mL}$ water and the product extracted with ethyl acetate. The organic phase of each reaction, when gathered were successively washed with $5 \%(w / v) \mathrm{NaHCO}_{3}$ and water, dried over anhydrous $\mathrm{Na}_{2} \mathrm{SO}_{4}$ and filtered. After removal of ethyl acetate under vacuum, the pure products of each of those reactions were obtained [50].

\subsection{1. (E)-Methyl-3-(3,4,5-trimethoxyphenyl)acrylate (2)}

Yield 93\%; white solid, m.p.: $135-136{ }^{\circ} \mathrm{C}$; MM: $252.10 \mathrm{~g} / \mathrm{mol} ;{ }^{1} \mathrm{H}$ NMR $\left(200 \mathrm{MHz}, \mathrm{CDCl}_{3}\right) \delta_{\mathrm{H}} 7.59$ $(\mathrm{d}, J=16.0 \mathrm{~Hz}, 1 \mathrm{H}), 6.73(\mathrm{~s}, 2 \mathrm{H}), 6.33(\mathrm{~d}, J=16.0 \mathrm{~Hz}, 1 \mathrm{H}), 3.87(\mathrm{~s}, 9 \mathrm{H}), 3.79(\mathrm{~s}, 3 \mathrm{H}) .{ }^{13} \mathrm{C} \mathrm{NMR}(50 \mathrm{MHz}$, $\left.\mathrm{CDCl}_{3}\right) \delta_{\mathrm{C}} 167.5,153.5,144.9,140.1,129.9,117.1,105.2,61.1,56.2,51.8, \mathrm{IR} v_{\max }\left(\mathrm{KBr}, \mathrm{cm}^{-1}\right) 3003,1697$, $2943,2837,1632,1040,1005,1582,1506,851[51,52]$.

\subsection{2. (E)-Ethyl-3-(3,4,5-trimethoxyphenyl)acrylate (3)}

Yield 98.8\%; white solid, MM: $266.12 \mathrm{~g} / \mathrm{mol}$, m.p.: $65-66{ }^{\circ} \mathrm{C} ;{ }^{1} \mathrm{H}$ NMR $\left(200 \mathrm{MHz}, \mathrm{CDCl}_{3}\right) \delta_{\mathrm{H}} 7.53$ $(\mathrm{d}, J=16.0 \mathrm{~Hz}, 1 \mathrm{H}), 6.68(\mathrm{~s}, 2 \mathrm{H}), 6.28(\mathrm{~d}, J=16.0 \mathrm{~Hz}, 1 \mathrm{H}), 4.19(\mathrm{q}, J=6.0 \mathrm{~Hz}, 2 \mathrm{H}), 3.81(\mathrm{~s}, 9 \mathrm{H}), 1.27(\mathrm{t}$, $J=6.0 \mathrm{~Hz}, 3 \mathrm{H}),{ }^{13} \mathrm{C} \mathrm{NMR}\left(50 \mathrm{MHz}, \mathrm{CDCl}_{3}\right) \delta_{\mathrm{C}} 166.8,153.3,144.5,139.9,129.8,117.4,105.1,60.8,60.4$, 56.0, 14.3, IR $v_{\max }\left(\mathrm{KBr}, \mathrm{cm}^{-1}\right)$ 2999, 2974, 2945, 2837, 1701, 1634, 1038, 997, 1583, 1506, 872 [52].

\subsection{3. (E)-Propyl-3-(3,4,5-trimethoxyphenyl)acrylate (4)}

Yield 93\%, beige solid, MM: $280.13 \mathrm{~g} / \mathrm{mol}$, m.p.: $97-100{ }^{\circ} \mathrm{C} ;{ }^{1} \mathrm{H}$ NMR $\left(200 \mathrm{MHz}, \mathrm{CDCl}_{3}\right) \delta_{\mathrm{H}} 7.58$ $(\mathrm{d}, J=16.0 \mathrm{~Hz}, 1 \mathrm{H}), 6.74(\mathrm{~s}, 2 \mathrm{H}), 6.34(\mathrm{~d}, J=16.0 \mathrm{~Hz}, 1 \mathrm{H}), 4.15(\mathrm{t}, J=6.0 \mathrm{~Hz}, 2 \mathrm{H}), 3.87(\mathrm{~s}, 9 \mathrm{H}), 1.72(\mathrm{dt}$, $J=6.0,8.0 \mathrm{~Hz}, 2 \mathrm{H}), 0.98(\mathrm{t}, J=8.0 \mathrm{~Hz}, 3 \mathrm{H}),{ }^{13} \mathrm{C} \mathrm{NMR}\left(50 \mathrm{MHz}, \mathrm{CDCl}_{3}\right) \delta_{\mathrm{C}} 167.1,153.5,144.6,140.0$, 130.0, 117.6, 105.2, 66.2, 61.0, 56.2, 22.2, 10.6, IR $v_{\max }\left(\mathrm{KBr}, \mathrm{cm}^{-1}\right)$ 3003, 2941, 2841, 1697, 1632, 1005, $1585,1506,835$ [53].

\subsection{4. (E)-Butyl-3-(3,4,5-trimethoxyphenyl)acrylate (5)}

Yield 99.6\%, brown solid, MM: $294.15 \mathrm{~g} / \mathrm{mol}$, m.p.: $74-75{ }^{\circ} \mathrm{C} ;{ }^{1} \mathrm{H}$ NMR $\left(200 \mathrm{MHz}, \mathrm{CDCl}_{3}\right) \delta_{\mathrm{H}} 7.57$ $(\mathrm{d}, J=16.0 \mathrm{~Hz}, 1 \mathrm{H}), 6.73(\mathrm{~s}, 2 \mathrm{H}), 6.33(\mathrm{~d}, J=16.0 \mathrm{~Hz}, 1 \mathrm{H}), 4.19(\mathrm{t}, J=6.0 \mathrm{~Hz}, 2 \mathrm{H}), 3.86(\mathrm{~s}, 6 \mathrm{H}), 3.85$ $(\mathrm{s}, 3 \mathrm{H}), 1.75-1.59(\mathrm{~m}, 2 \mathrm{H}), 1.52-1.32(\mathrm{~m}, 2 \mathrm{H}), 0.94(\mathrm{t}, J=8,0 \mathrm{~Hz}, 3 \mathrm{H}),{ }^{13} \mathrm{C} \mathrm{NMR}\left(50 \mathrm{MHz}, \mathrm{CDCl}_{3}\right) \delta_{\mathrm{C}}$ $167.1,153.5,144.6,140.1,130.0,117.6,105.2,64.5,61.0,56.2,30.9,19.3,13.8, \mathrm{IR} v_{\max }\left(\mathrm{KBr}, \mathrm{cm}^{-1}\right) 2990$, $2965,2943,2841,1697,1638,1005,1582,1506,845$ [54].

\subsection{5. (E)-2-Methoxyethyl-3-(3,4,5-trimethoxyphenyl)acrylate (8)}

Yield 97\%, brown oil, MM: 296,13 g/mol, m.p.: 60-62 ${ }^{\circ} \mathrm{C} ;{ }^{1} \mathrm{H}$ NMR $\left(200 \mathrm{MHz}, \mathrm{CDCl}_{3}\right) \delta_{\mathrm{H}} 7.61$ $(\mathrm{d}, J=16.0 \mathrm{~Hz}, 1 \mathrm{H}), 6.74(\mathrm{~s}, 2 \mathrm{H}), 6.39(\mathrm{~d}, J=16.0 \mathrm{~Hz}, 1 \mathrm{H}), 4.35(\mathrm{~d}, J=4.0 \mathrm{~Hz}, 2 \mathrm{H}), 3.86(\mathrm{~s}, 9 \mathrm{H}), 3.65(\mathrm{t}$, $J=4.0 \mathrm{~Hz}, 2 \mathrm{H}), 3.41(\mathrm{~s}, 3 \mathrm{H}),{ }^{13} \mathrm{C} \mathrm{NMR}\left(50 \mathrm{MHz}, \mathrm{CDCl}_{3}\right) \delta_{\mathrm{C}} 167.0,153.5,145.2,140.1,129.9,117.1,105.3$, 70.7, 63.6, 61.0, 59.2, 56.2, IR $v_{\max }\left(\mathrm{KBr}, \mathrm{cm}^{-1}\right)$ 3019, 2963, 2939, 2841, 1709, 1638, 1037, 1001, 1584, 1504, LS-MALDI TOF/TOF $m / z$ [M] 296.1244 (calcd. for $\mathrm{C}_{15} \mathrm{H}_{20} \mathrm{O}_{6}, 296.1260$ ). 
4.1.6. (E)-Isopropyl 3-(3,4,5-Trimethoxyphenyl)acrylate (9)

Yield 96\%, brown oil, MM: $280.13 \mathrm{~g} / \mathrm{mol} ;{ }^{1} \mathrm{H}$ NMR $\left(200 \mathrm{MHz}, \mathrm{CDCl}_{3}\right) \delta_{\mathrm{H}} 7.54(\mathrm{~d}, J=16.0 \mathrm{~Hz}, 1 \mathrm{H})$, $6.71(\mathrm{~s}, 1 \mathrm{H}), 6.29(\mathrm{~d}, J=16.0 \mathrm{~Hz}, 1 \mathrm{H}), 5.09$ (hept, $J=6.00,1 \mathrm{H}), 3.83(\mathrm{~s}, 9 \mathrm{H}), 1.29-1.19(\mathrm{~m}, 6 \mathrm{H}),{ }^{13} \mathrm{C} \mathrm{NMR}$ $\left(50 \mathrm{MHz}, \mathrm{CDCl}_{3}\right) \delta_{\mathrm{C}} 166.5,153.4,144.4,139.9,130.0,118.0,105.2,67.9,61.0,56.1,22.0, \mathrm{IR} v_{\max }(\mathrm{KBr}$, $\mathrm{cm}^{-1}$ ) 3019, 2978, 2938, 2841, 1703, 1638, 1584, 1505 [55].

\subsection{General Procedure for Synthesis of Compounds 6, 7, 10 and $\mathbf{1 3}$}

To a solution of 3,4,5-trimethoxycinnamic acid $(0.1 \mathrm{~g}, 0.42 \mathrm{mmol})$ dissolved in $5.0 \mathrm{~mL}$ of acetone, $0.22 \mathrm{~mL}(1.68 \mathrm{mmol})$ of $\mathrm{Et}_{3} \mathrm{~N}$ and $0.43 \mathrm{mmol}$ of alkyl halide ( $\mathrm{RBr}$ or $\mathrm{RCl}$ ) were added and stirred and the reaction mixture was refluxed for $24 \mathrm{~h}$, except for the reaction of synthesis of compound 10, which was stirred for $48 \mathrm{~h}$. After cooling at room temperature, the acetone of each reaction was removed under reduced pressure. The remaining content of those reactions were then diluted with $10 \mathrm{~mL}$ ethyl acetate and transferred to the separator funnel containing $10 \mathrm{~mL}$ of water. The products were extracted with $10 \mathrm{~mL}$ ethyl acetate three times and the during the organic phase when gathered, were successively washed with $5 \%(w / v) \mathrm{NaHCO}_{3}$ and water, dried over anhydrous $\mathrm{Na}_{2} \mathrm{SO}_{4}$ and filtered. After the removal of ethyl acetate under vacuum, the products were isolated with silica gel 60-column chromatography (eluent: hexane-ethyl acetate) [56].

\subsection{1. (E)-Pentyl 3-(3,4,5-trimethoxyphenyl)acrylate (6)}

Yield 66.5\%, white solid, MM: $308.16 \mathrm{~g} / \mathrm{mol}$, m.p.: $105-106{ }^{\circ} \mathrm{C} ;{ }^{1} \mathrm{H}$ NMR $\left(200 \mathrm{MHz}, \mathrm{CDCl}_{3}\right) \delta_{\mathrm{H}}$ $7.56(\mathrm{~d}, J=16.0 \mathrm{~Hz}, 1 \mathrm{H}), 6.72(\mathrm{~s}, 2 \mathrm{H}), 6.32(\mathrm{~d}, J=16.0 \mathrm{~Hz}, 1 \mathrm{H}), 4.16(\mathrm{t}, J=6.0 \mathrm{~Hz}, 2 \mathrm{H}), 3.84(\mathrm{~m}, 9 \mathrm{H})$, $1.76-1.58(\mathrm{~m}, 2 \mathrm{H}), 1.41-1.27(\mathrm{~m}, 4 \mathrm{H}), 0.90(\mathrm{t}, J=6,0 \mathrm{~Hz}, 3 \mathrm{H}),{ }^{13} \mathrm{C} \mathrm{NMR}\left(50 \mathrm{MHz}, \mathrm{CDCl}_{3}\right) \delta_{\mathrm{C}} 167.1$, 153.4, 144.5, 140.0, 130.0, 117.5, 105.1, 64.7, 61.0, 56.1, 28.5, 28.2, 22.4, 14.0, IR $v_{\max }\left(\mathrm{KBr}, \mathrm{cm}^{-1}\right) 2997$, 2957, 2934, 2857, 1711, 1638, 1009, 1584, 1505, 825, LS-MALDI TOF/TOF $m / z$ [M] 308.1621 (calcd. for $\left.\mathrm{C}_{17} \mathrm{H}_{24} \mathrm{O}_{5}, 308.1624\right)$.

\subsection{2. (E)-Decyl-3-(3,4,5-trimethoxyphenyl)acrylate (7)}

Yield 64.5\%, white solid, MM: $378.24 \mathrm{~g} / \mathrm{mol}$, m.p.: $37-38{ }^{\circ} \mathrm{C} ;{ }^{1} \mathrm{H}$ NMR $\left(200 \mathrm{MHz}, \mathrm{CDCl}_{3}\right) \delta_{\mathrm{H}} 7.58$ $(\mathrm{d}, J=16.0 \mathrm{~Hz}, 1 \mathrm{H}), 6.74(\mathrm{~s}, 2 \mathrm{H}), 6.34(\mathrm{~d}, J=16.0 \mathrm{~Hz}, 1 \mathrm{H}), 4.18(\mathrm{t}, J=6,0 \mathrm{~Hz}, 2 \mathrm{H}), 3.87(\mathrm{~s}, 9 \mathrm{H}), 1.76-1.60$ $(\mathrm{m}, 2 \mathrm{H}), 1.35-1.15(\mathrm{~m}, 14 \mathrm{H}), 0.86(\mathrm{t}, J=6.0 \mathrm{~Hz}, 3 \mathrm{H}) .{ }^{13} \mathrm{C} \mathrm{NMR}\left(50 \mathrm{MHz}, \mathrm{CDCl}_{3}\right) \delta_{\mathrm{C}} 167.1,153.5,144.6$, 140.1, 130.1, 117.6, 105.2, 64.6. 61.1, 56.2, 32.0, 29.6, 29.4, 28.8, 26.1, 22.8, 14.2, IR $v_{\max }\left(\mathrm{KBr}, \mathrm{cm}^{-1}\right) 2995$, 2953, 2926, 2853, 1713, 1636, 1007, 1582, 1504, 827, LS-MALDI TOF/TOF: $m / z$ [M] 378.2406 (calcd. for $\left.\mathrm{C}_{22} \mathrm{H}_{34} \mathrm{O}_{5} 378.2406\right)$.

\subsection{3. (E)-Benzhydryl 3-(3,4,5-trimethoxyphenyl)acrylate (10)}

Yield 41.6\% colorless oil, MM: $404.16 \mathrm{~g} / \mathrm{mol}^{1}{ }^{1} \mathrm{H}$ NMR $\left(200 \mathrm{MHz}, \mathrm{CDCl}_{3}\right) \delta_{\mathrm{H}} 7.67(\mathrm{~d}, J=16.0 \mathrm{~Hz}$, 1H), 7.41-7.22 (m, 10H), $7.02(\mathrm{~s}, 1 \mathrm{H}), 6.76(\mathrm{~s}, 2 \mathrm{H}), 6.48(\mathrm{~d}, J=16.0 \mathrm{~Hz}, 1 \mathrm{H}), 3.88(\mathrm{~s}, 9 \mathrm{H}),{ }^{13} \mathrm{C}$ NMR $\left(50 \mathrm{MHz}, \mathrm{CDCl}_{3}\right) \delta_{\mathrm{C}} 166.0,153.5,145.5,140.2,129.9,128.6,128.0,127.2,126.6,117.3,105.3,77.1,61.0,56.2$. IR $v_{\max }\left(\mathrm{KBr}, \mathrm{cm}^{-1}\right) 3028,3001,2938,2837,1709,1636,1001,1582,1504,825$, LC-MALDI TOF/TOF: $m / z[\mathrm{M}]^{+} 404.1627$ (calcd. for $\mathrm{C}_{25} \mathrm{H}_{24} \mathrm{O}_{5}, 404.1624$ ).

\subsection{4. (E)-4-Methylphenethyl 3-(3,4,5-Trimethoxyphenyl)acrylate (13)}

Yield 30.6\%, white solid, MM: $356.26 \mathrm{~g} / \mathrm{mol}$, m.p.: $105-106{ }^{\circ} \mathrm{C} ;{ }^{1} \mathrm{H} \mathrm{NMR}\left(200 \mathrm{MHz}, \mathrm{CDCl}_{3}\right) \delta_{\mathrm{H}}$ $7.60(\mathrm{~d}, J=16.0 \mathrm{~Hz}, 1 \mathrm{H}), 7.14(\mathrm{~s}, 4 \mathrm{H}), 6.75(\mathrm{~s}, 2 \mathrm{H}), 6.35(\mathrm{~d}, J=16.0 \mathrm{~Hz}, 1 \mathrm{H}), 4.41(\mathrm{t}, J=8.0 \mathrm{~Hz}, 2 \mathrm{H}), 3.90(\mathrm{~s}$, 9H), $2.96(\mathrm{t}, J=8.0 \mathrm{~Hz}, 2 \mathrm{H}), 2.33(\mathrm{~s}, 3 \mathrm{H}),{ }^{13} \mathrm{C} \mathrm{NMR}\left(50 \mathrm{MHz}, \mathrm{CDCl}_{3}\right) \delta_{\mathrm{C}} 166.9,153.4,144.8,140.1,136.1$, 134.8, 129.9, 129.2, 128.8, 117.3, 105.2, 65.2, 61.0, 56.1, 34.8, $21.1 \mathrm{IR} v_{\max }\left(\mathrm{KBr}, \mathrm{cm}^{-1}\right) 3001,2941,2845$, $1703,1632,1045,1003,1585,1506,820$ LC-MALDI TOF/TOF $m / z$ [M] 356.1643 (calcd. for $\mathrm{C}_{21} \mathrm{H}_{24} \mathrm{O}_{5}$, 356.1624). 


\subsection{General Procedure for Synthesis of Compounds $\mathbf{1 1}$ and $\mathbf{1 2}$}

To a $50 \mathrm{~mL}$ round-bottom flask with $0.1 \mathrm{~g}(0.42 \mathrm{mmol})$ of 3,4,5-trimethoxycinnamic acid connected to a reflux condenser was added $0.03 \mathrm{~mL}(0.42 \mathrm{mmol})$ of thionyl chloride, the reaction mixture was stirred and refluxed for $1 \mathrm{~h}$ and the reaction was finalized after adding $0.42 \mathrm{mmol}$ of respective $\mathrm{ROH}$ (carvacrol or phenethyl alcohol), followed by an additional hour of stir and reflux. After cooling at room temperature, the remaining content of those reactions was then diluted with $10 \mathrm{~mL}$ ethyl acetate and transferred to the separator funnel containing $10 \mathrm{~mL}$ of water. The products were extracted with $10 \mathrm{~mL}$ ethyl acetate three times and the organic phase when gathered were successively washed with $5 \%(w / v) \mathrm{NaHCO}_{3}$ and water, dried over anhydrous $\mathrm{Na}_{2} \mathrm{SO}_{4}$ and filtered. After the removal of ethyl acetate under vacuum, the products were isolated with silica gel 60-column chromatography (eluent: hexane-ethyl acetate) [57].

\subsection{1. (E)-Carvacryl-3-(3,4,5-trimethoxyphenyl)acrylate (11)}

Yield 52\%, White solid, MM: $370.18 \mathrm{~g} / \mathrm{mol}$, m.p.: $145-146{ }^{\circ} \mathrm{C} ;{ }^{1} \mathrm{H}$ NMR $\left(200 \mathrm{MHz}, \mathrm{CDCl}_{3}\right) \delta_{\mathrm{H}}$ $7.81(\mathrm{~d}, J=16.0 \mathrm{~Hz}, 1 \mathrm{H}), 7.18(\mathrm{~d}, J=8.0 \mathrm{~Hz}, 1 \mathrm{H}), 7.04(\mathrm{~d}, J=8.0 \mathrm{~Hz}, 1 \mathrm{H}), 6.94(\mathrm{~s}, 1 \mathrm{H}), 6.83(\mathrm{~s}, 2 \mathrm{H}), 6.58$ $(\mathrm{d}, J=16.0 \mathrm{~Hz}, 1 \mathrm{H}), 3.91(\mathrm{~s}, 9 \mathrm{H}), 2.91(\mathrm{Hept}, J=6.0 \mathrm{~Hz}, 1 \mathrm{H}), 2.18(\mathrm{~s}, 3 \mathrm{H}), 1.26(\mathrm{~s}, 3 \mathrm{H}), 1.23(\mathrm{~s}, 3 \mathrm{H}),{ }^{13} \mathrm{C}$ NMR $\left(50 \mathrm{MHz}, \mathrm{CDCl}_{3}\right) \delta_{\mathrm{C}} 165.3,153.6,149.4,148.2,146.5,140.5,131.0,129.8,127.4,124.3,119.9,116.5$, 105.5, 61.1, 56.3, 33.7, 24.0, 16.0, IR $v_{\max }\left(\mathrm{KBr}, \mathrm{cm}^{-1}\right)$ 3022, 2997, 2959, 2833, 1722, 1632, 1005, 1582, 1504, $822[58]$.

\subsection{2. (E)-Phenethyl 3-(3,4,5-trimethoxyphenyl)acrylate (12)}

Yield 83\%, white solid, MM: $342.15 \mathrm{~g} / \mathrm{mol}$, m.p.: $110-112{ }^{\circ} \mathrm{C} ;{ }^{1} \mathrm{H}$ NMR $\left(200 \mathrm{MHz}, \mathrm{CDCl}_{3}\right) \delta_{\mathrm{H}} 7.60$ $(\mathrm{d}, J=16.0 \mathrm{~Hz}, 1 \mathrm{H}), 7.32-7.24(\mathrm{~m}, 5 \mathrm{H}), 6.75(\mathrm{~s}, 2 \mathrm{H}), 6.34(\mathrm{~d}, J=16.0 \mathrm{~Hz}, 1 \mathrm{H}), 4.44(\mathrm{t}, J=8.0 \mathrm{~Hz}, 2 \mathrm{H}), 3.88$ $(\mathrm{s}, 9 \mathrm{H}), 3.03(\mathrm{t}, J=8.0 \mathrm{~Hz}, 2 \mathrm{H}),{ }^{13} \mathrm{C}$ NMR $\left(50 \mathrm{MHz}, \mathrm{CDCl}_{3}\right) \delta_{\mathrm{C}} 167.0,153.5,144.9,140.1,137.9,130.0$, $129.0,126.7,117.3,105.3,65.1,61.0,56.2,35.3, \mathrm{IR} v_{\max }\left(\mathrm{KBr}, \mathrm{cm}^{-1}\right)$ 3007, 2945, 2843, 1707, 1632, 1042, $1582,1506,843$ [59].

\subsection{General Synthesis of Amides}

To a round-bottom flask, $0.1 \mathrm{~g}(0.42 \mathrm{mmol})$ of 3,4,5-trimethoxycinnamic was dissolved in 0.84 $\mathrm{mL}$ of DMF and $0.06 \mathrm{~mL}(0.42 \mathrm{mmol})$ of trimethylamine. The solution was cooled in an ice water bath and $0.42 \mathrm{mmol}$ of amine were added, followed by a solution of $0.42 \mathrm{mmol}$ of BOP in $0.84 \mathrm{~mL}$ of $\mathrm{CH}_{2} \mathrm{Cl}_{2}$. The mixture was stirred at $0{ }^{\circ} \mathrm{C}$ for $30 \mathrm{~min}$ and then at room temperature for $3 \mathrm{~h}$. After of the removal of $\mathrm{CH}_{2} \mathrm{Cl}_{2}$ under reduced pressure, the solution was diluted with $10 \mathrm{~mL}$ of ethyl acetate and transferred to separator funnel containing $10 \mathrm{~mL}$ of water. The products were extracted with $10 \mathrm{~mL}$ ethyl acetate three times and the organic phase when gathered were washed successively with $1 \mathrm{~N}$ $\mathrm{HCl}$, water, $1 \mathrm{M} \mathrm{NaHCO}_{3}$ and water, dried over $\mathrm{Na}_{2} \mathrm{SO}_{4}$, Filtered and evaporated. The residues were purified on a silica gel 60 column chromatography (eluent: hexane-ethyl acetate) [60].

\subsection{1. (E)-N-Butyl-3-(3,4,5-trimethoxyphenyl)acrylamide (14)}

Yield 80\%, white solid, MM: 293.16 g/mol, m.p.: $225-226{ }^{\circ} \mathrm{C} ;{ }^{1} \mathrm{H}$ NMR $\left(200 \mathrm{MHz}, \mathrm{CDCl}_{3}\right) \delta_{\mathrm{H}} 7.50$ $(\mathrm{d}, J=14.0 \mathrm{~Hz}, 1 \mathrm{H}), 6.58(\mathrm{~s}, 2 \mathrm{H}), 6.35(\mathrm{~d}, J=16.0 \mathrm{~Hz}, 1 \mathrm{H}), 6.08(\mathrm{~s}, 1 \mathrm{H}), 3.81(\mathrm{~s}, 9 \mathrm{H}), 3.35(\mathrm{q}, J=6.0 \mathrm{~Hz}$, $2 \mathrm{H}), 1.60-1.23(\mathrm{~m}, 4 \mathrm{H}), 0.90(\mathrm{t}, J=7.1 \mathrm{~Hz}, 3 \mathrm{H}),{ }^{13} \mathrm{C}$ NMR $\left(50 \mathrm{MHz}, \mathrm{CDCl}_{3}\right) \delta_{\mathrm{C}} 166.0,153.4,140.6,139.4$, 130.6, 120.4, 104.9, 61.0, 56.1, 39.6, 31.8, 20.2, 13.8, IR $v_{\max }\left(\mathrm{KBr}, \mathrm{cm}^{-1}\right)$ 3290, 3005, 2957, 2932, 2841, 1653, 1614,1579 [61].

\subsection{2. (E)-N-Benzyl-3-(3,4,5-trimethoxyphenyl)acrylamide (15)}

Yied 99.7\%, white solid, MM: 327.15 g/mol, m.p.: 180-181 ${ }^{\circ} \mathrm{C} ;{ }^{1} \mathrm{H}$ NMR $\left(200 \mathrm{MHz}, \mathrm{CDCl}_{3}\right) \delta_{\mathrm{H}} 7.55$ $(\mathrm{d}, J=16.0 \mathrm{~Hz}, 1 \mathrm{H}), 7.27(\mathrm{~s}, 5 \mathrm{H}), 6.67(\mathrm{~s}, 2 \mathrm{H}), 6.45(\mathrm{~d}, J=16.0 \mathrm{~Hz}, 1 \mathrm{H}), 4.51(\mathrm{~d}, 2 \mathrm{H}), 3.83(\mathrm{~s}, 3 \mathrm{H}), 3.78$ 
$(\mathrm{s}, 6 \mathrm{H}),{ }^{13} \mathrm{C} \mathrm{NMR}\left(50 \mathrm{MHz}, \mathrm{CDCl}_{3}\right) \delta_{\mathrm{C}} 166.0,153.3,141.0,139.3,138.2,130.4,128.6,127.7,127.4,120.2$, 104.8, 60.9, 56.0, 43.7, IR $v_{\max }\left(\mathrm{KBr}, \mathrm{cm}^{-1}\right)$ 3269, 2990, 2957, 2934, 2835,1653, 1620, 1582, 1505, 820 [62].

\subsection{3. (E)-N-(4-Methylbenzyl)-3-(3,4,5-trimethoxyphenyl)acrylamide (16)}

Yield 97\%, white solid, MM: $341.16 \mathrm{~g} / \mathrm{mol}$, m.p.: $203-205^{\circ} \mathrm{C} ;{ }^{1} \mathrm{H}$ NMR $\left(200 \mathrm{MHz}, \mathrm{CDCl}_{3}\right) \delta_{\mathrm{H}} 7.55$ $(\mathrm{d}, J=16.0 \mathrm{~Hz}, 1 \mathrm{H}), 7.15(\mathrm{q}, J=8.0 \mathrm{~Hz}, 4 \mathrm{H}), 6.68(\mathrm{~s}, 2 \mathrm{H}), 6.37(\mathrm{~d}, J=16.0 \mathrm{~Hz}, 1 \mathrm{H}), 6.24(\mathrm{~m}, 1 \mathrm{H}), 4.48(\mathrm{~d}$, $J=6.0 \mathrm{~Hz}, 2 \mathrm{H}), 2.31(\mathrm{~s}, 3 \mathrm{H}),{ }^{13} \mathrm{C}$ NMR $\left(50 \mathrm{MHz}, \mathrm{CDCl}_{3}\right) \delta_{\mathrm{C}} 165.9,153.4,141.2,139.5,137.3,135.2,130.5$, 129.4, 127.9, 120.1, 104.9, 61.0, 56.2, 43.7, 21.2, IR $v_{\max }\left(\mathrm{KBr}, \mathrm{cm}^{-1}\right)$ 3292, 3001, 2934, 2837, 1653, 1607, 1580, 1504, 831 LS-MALDI TOF/TOF $m / z$ [M + H] 342.1679 (calcd. for $\mathrm{C}_{20} \mathrm{H}_{23} \mathrm{NO}_{4}, 342.1706$ ).

4.4.4. (E)-N-(4-Methoxybenzyl)-3-(3,4,5-trimethoxyphenyl)acrylamide (17)

Yield 71\%, White solid, MM: $357.16 \mathrm{~g} / \mathrm{mol}$, m.p.: $225-226{ }^{\circ} \mathrm{C} ;{ }^{1} \mathrm{H}$ NMR $\left(200 \mathrm{MHz}, \mathrm{CDCl}_{3}\right) \delta_{\mathrm{H}} 7.54$ $(\mathrm{d}, J=16.0 \mathrm{~Hz}, 1 \mathrm{H}), 7.28-7.16(\mathrm{~m}, 2 \mathrm{H}), 6.88-6.79(\mathrm{~m}, 2 \mathrm{H}), 6.68(\mathrm{~s}, 2 \mathrm{H}), 6.34(\mathrm{~d}, J=14.0 \mathrm{~Hz}, 1 \mathrm{H}), 4.46(\mathrm{~d}$, $J=4.0 \mathrm{~Hz}, 2 \mathrm{H}), 3.85(\mathrm{~s}, 3 \mathrm{H}), 3.83(\mathrm{~s}, 6 \mathrm{H}), 3.78(\mathrm{~s}, 3 \mathrm{H}),{ }^{13} \mathrm{C} \mathrm{NMR}\left(50 \mathrm{MHz}, \mathrm{CDCl}_{3}\right) \delta_{\mathrm{C}} 165.9,159.1,153.4$, $141.2,139.6,130.5,130.3,129.3,120.0,114.2,105.0,61.0,56.1,55.3,43.4, \mathrm{IR} v_{\max }\left(\mathrm{KBr}, \mathrm{cm}^{-1}\right) 3318,2990$, $2957,2934,2837,1653,1618,1581,1508,829$ [63].

\subsection{5. (E)-N-(4-Chlorobenzyl)-3-(3,4,5-trimethoxyphenyl)acrylamide (18)}

Yield 91.2\%, White solid, MM: $361.11 \mathrm{~g} / \mathrm{mol}$, m.p.: $215-218{ }^{\circ} \mathrm{C} ;{ }^{1} \mathrm{H}$ NMR $\left(200 \mathrm{MHz}, \mathrm{CDCl}_{3}\right) \delta_{\mathrm{H}}$ $7.56(\mathrm{~d}, J=16.0 \mathrm{~Hz}, 1 \mathrm{H}), 7.40-7.11(\mathrm{~m}, 4 \mathrm{H}), 6.70(\mathrm{~s}, 2 \mathrm{H}), 6.38(\mathrm{~d}, J=16.0 \mathrm{~Hz}, 2 \mathrm{H}), 4.50(\mathrm{~d}, J=6.0 \mathrm{~Hz}, 2 \mathrm{H})$, $3.85(\mathrm{~s}, 3 \mathrm{H}), 3.83(\mathrm{~s}, 6 \mathrm{H}),{ }^{13} \mathrm{C} \mathrm{NMR}\left(50 \mathrm{MHz}, \mathrm{CDCl}_{3}\right) \delta_{\mathrm{C}} 166.0,153.4,141.5,139.9,136.9,133.3,130.4$, 129.2, 128.9, 119.8, 105.0, 61.0, 56.1, 43.1, IR $v_{\max }\left(\mathrm{KBr}, \mathrm{cm}^{-1}\right)$ 3294, 3044, 2959, 2932, 2837, 1651, 1616, $1582,1506,825$ [64].

\subsection{6. (E)-N,N-Diethyl-3-(3,4,5-trimethoxyphenyl)acrylamide (19)}

Yield 85\%, white solid, MM: $293.16 \mathrm{~g} / \mathrm{mol}$, m.p.: $197-198{ }^{\circ} \mathrm{C}^{\prime}{ }^{1} \mathrm{H}$ NMR $\left(200 \mathrm{MHz}, \mathrm{CDCl}_{3}\right) \delta_{\mathrm{H}} 7.58$ $(\mathrm{d}, J=14.0 \mathrm{~Hz}, 1 \mathrm{H}), 6.67(\mathrm{~d}, J=16.0 \mathrm{~Hz}, 3 \mathrm{H}), 3.86(\mathrm{~s}, 6 \mathrm{H}), 3.83(\mathrm{~s}, 3 \mathrm{H}) 3.46(\mathrm{q}, J=8.0 \mathrm{~Hz}, 4 \mathrm{H}), 1.31-1.11$ $(\mathrm{m}, 6 \mathrm{H}),{ }^{13} \mathrm{C}$ NMR $\left(50 \mathrm{MHz}, \mathrm{CDCl}_{3}\right) \delta_{\mathrm{C}} 165.7,153.0,142.5,139.5,131.1,117.0,105.0,61.0,56.2,42.4,41.1$, 15.1, 13.3, IR $v_{\max }\left(\mathrm{KBr}, \mathrm{cm}^{-1}\right)$ 2995, 2968, 2938, 2837, 1649, 1597, 1506, 856 [65].

\subsection{Cell Cultures and Conditions}

Human glioblastoma (GBM) cell line U87MG (American Type Culture Collection; Rockville, MD, USA) within passage number $15-20$ were grown in an incubator at $37^{\circ} \mathrm{C}$ in a humidified atmosphere of $5 \% \mathrm{CO}_{2}$. They were grown in Eagle's Minimal Essential Medium from Sigma-Aldrich (Saint Louis, MO, USA), supplemented with $10 \%$ fetal bovine serum (FBS) and $100 \mu \mathrm{g} / \mathrm{mL}$ of each of the following antibiotics: penicillin and streptomycin [66].

\subsection{In Vitro Evaluation of Anticancer Activity by MTT and LDH Assays}

\subsubsection{MTT Assay}

To examine the effects of compounds on cell viability, an MTT assay was performed. U87MG cells were seeded at $1 \times 10^{4}$ cells per well in 96-well plate and allowed to attach for $24 \mathrm{~h}$. Then the cells were exposed to different concentrations of $\mathbf{2 - 1 9}(0.78,1.56,3.125,6.25,12.5,25$ and $50 \mu \mathrm{g} / \mathrm{mL})$ for $48 \mathrm{~h}$. All the compounds were dissolved in dimethyl sulfoxide (DMSO), and diluted in serum-free culture medium. After the incubation, a 3-(4,5-dimethylthiazol-2-yl)-2,5-diphenyltetrazolium bromide (MTT) solution was applied to cell cultures according to the manufacturer's instructions (Cayman Chemical Company ${ }^{\circledR}$, Ann Arbor, MI, USA). After 3 h of incubation, MTT-formazan crystals were dissolved in DMSO and absorbance was measured at $570 \mathrm{~nm}$ on a plate reader and compared with control, untreated cells. The half-maximal inhibitory concentration values $\left(\mathrm{IC}_{50}\right)$ were determined by MTT assay performed in four replicates. 


\subsubsection{LDH Assay}

Cellular viability was assessed by the assay of LDH leakage from the cell [67]. A LDH cytotoxicity assay kit purchased from Cayman Chemical Company ${ }^{\circledR}$ (Ann Arbor, MI, USA) was used following instructions provided by the manufacturer. Briefly, the cells were seeded at $10^{6}$ cells /well in 48 -well plates, treated with compound 10 as described above for $48 \mathrm{~h}$. At the end of incubation $100 \mu \mathrm{L}$ of culture medium was collected and transferred to a fresh 48 -well plate. $100 \mu \mathrm{L}$ of reaction mixture was added to each well and incubated for $30 \mathrm{~min}$ at room temperature. Finally, the absorbance of the cultures was measured at $490 \mathrm{~nm}$ using a microplate reader [68].

\subsection{Total Antioxidant Capacity and Total Oxidant Status Assays}

The commercially available kits were purchased from (Rel Assay Diagnostics ${ }^{\circledR}$, Gaziantep, Turkey) to estimate the level of TAS and TOS. As a summary, the cells were seeded at $10^{6}$ cells/well in 48 -well plates, treated with compound $\mathbf{1 0}$ as described above. After $48 \mathrm{~h}$ incubation, plasma samples of treated and untreated cultures were transferred to a new plate, mixed with reaction solution and incubate for $10 \mathrm{~min}$ at room temperature. After that, the absorbance was read spectrophotometrically and the level of TAS and TOS were calculated according to the given equation.

\subsection{Apoptosis Detection by Hoechst 33,258 Staining}

The control and formulation treated cells were incubated for $48 \mathrm{~h}$ and were cultured in six-well cell culture plates for $48 \mathrm{~h}$. after incubation, the medium was removed and the cells were fixed with $4 \%$ paraformaldehyde in phosphate buffered saline at $4{ }^{\circ} \mathrm{C}$ for $30 \mathrm{~min}$. Following the washing cells three times with phosphate-buffered saline (PBS). The cells were then stained with $1 \mu \mathrm{L}$ Hoechst 33,258 $(5 \mu \mathrm{g} / \mathrm{mL}$; Sigma-Aldrich, Saint Louis, MO, USA) and incubated at room temperature in the dark for $5 \mathrm{~min}$. Changes in nuclear morphology were visualized under a fluorescent microscope (excitation, $350 \mathrm{~nm}$; emission, $460 \mathrm{~nm}$; Leica ${ }^{\circledR}$ DM IL LED, Wetzlar, Germany).

\subsection{RNA Extraction and Quantitative Reverse-Transcription Polymerase Chain Reaction Analyses}

$5 \times 10^{6}$ cells were incubated with $\mathrm{IC}_{50}$ concentrations of compound 10 in 6-well plate in $2 \mathrm{~mL}$ growth medium for $48 \mathrm{~h}$. Total RNA was isolated from cultured cells using PureLink ${ }^{\circledR}$ RNA Mini Kit (Invitrogen, Carlsbad, MA, USA) following the instructions described by the manufacturer. For quantitative reverse-transcription polymerase chain reaction (qRT-PCR), RNA was reverse-transcribed to cDNA by using a High-Capacity cDNA Reverse Transcription kit (Applied Biosystems, Foster City, CA, USA) according to the manufacturer's protocol. Real-time PCR analyses were performed using the resulting total cDNA on a TaqMan ${ }^{\circledR}$ custom plate (Applied Biosystems)

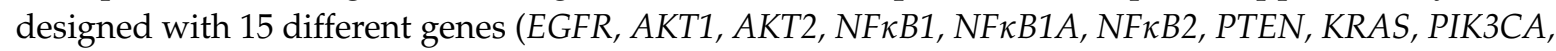
PIK3R1, TP53, RAF1, BRAF, DVL1, FOS). Results were normalized to the expression of 18SRNA. qRT-PCR and data collection were performed on 7500 Fast Real-Time PCR (Applied Biosystems). Data analyses were performed using the The Applied Biosystems 7500 Fast System SDS software (Foster City, CA, USA).

\subsection{Biosafety Evaluation}

Human peripheral blood cells were cultured in order to evaluate the biosafety of $\mathbf{1 0}$. To assess the cytotoxicity and genotoxicity potential of 10, MTT, LDH, Sister chromatid exchange (SCE) and 8-hydroxy-2'-deoxyguanosine assays were assessed on cultured blood cells [69,70].

\subsection{SCE Testing}

Peripheral blood samples were incubated with $10(50 \mu \mathrm{g} / \mathrm{mL})$ at $37{ }^{\circ} \mathrm{C}$ for $72 \mathrm{~h}$ in culture medium (PB-MAX Karyotyping Medium, Gibco ${ }^{\circledR}$, Baecelona, Spain) with $5.0 \mathrm{mg} / \mathrm{mL}$ of phytohemagglutinin (Sigma Aldrich, Steinheim, Germany). 5-Bromodeoxyuridine (BrdU) $(10 \mu \mathrm{g} / \mathrm{mL})$ was added to cell 
cultures at initiation. At $1.5 \mathrm{~h}$ before harvesting, colcemid $(0.5 \mu \mathrm{g} / \mathrm{mL})$ were added to cells. Then cells were treated with a hypotonic solution $(0.075 \mathrm{M} \mathrm{KCl})$, followed by three times fixation step in methanol/acetic acid $(3: 1, v / v)$. Cell suspensions were dropped on slides and air-dried. Three days later, the slides were stained according to the fluorescence plus Giemsa (FPG) procedure. Slides were observed under a fluorescence microscope and scores were calculated as SCEs per cell.

\subsection{Nucleic Acid Oxidation}

To detect the level of $8 \mathrm{OHdG}$ released into the extracellular space, in accordance with the provider's manual, a 8-Hydroxy-2'-deoxyguanosine assay kit (Cayman chemical, Ann Arbor, MI, USA) was used and performed in accordance with the provider's manual.

\subsection{Statistical Analysis}

All experiments with U87MGs were performed in four independent experiments and the results were expressed as the mean \pm standard error of the mean (SEM). Statistical analysis of data obtained from cell culture experiments was performed using to the statistical program SPSS software (version 20.0, SPSS, Chicago, IL, USA). One-way analysis of variance (ANOVA) followed by Duncan's test was used for statistical comparisons of quantitative data. A $p$-value less than 0.05 was regarded as significant.

\section{Conclusions}

The assessment of the anticancer potential of piplartine analogues (2-19) has shown that changes in trimethoxycinnamic structure may reveal novel drug candidate compounds, such as compound 10, which executed strong cytotoxic actions against the proliferation of U87MG cells. Compound $\mathbf{1 0}$ had a marked concentration-dependent inhibitory effect on the viability of brain cancer cells. Furthermore, in the mechanisms of cytotoxic activity of $\mathbf{1 0}$, apoptotic and oxidative processes were involved and showed good potential for altering other main molecular pathways (such as Akt and NF-kB signaling) and preventing tumor development. Moreover, 3-BTA exhibited non-genotoxic and non-cytotoxic properties on healthy human cells. The obtained results are the first showing the potential antitumor activity of the compound $\mathbf{1 0}$ in brain human cancer cells and giving directions for future investigations concerning a detailed assessment of pharmacological action and safe formulations.

Supplementary Materials: Supplementary materials are available on line.

Author Contributions: F.R.d.N. and O.O. performed the research, analyzed the data and wrote the paper. S.C.S.N.S. and J.N.B. helped in writing the paper. H.T. and D.P.d.S. designed the research and appraisal of the paper.

Funding: This research received no external funding.

Acknowledgments: This work was supported by the Brazilian agencies: Conselho Nacional de Desenvolvimento Científico e Tecnológico (CNPq), and Coordenação de Aperfeiçoamento de Pessoal de Nível Superior (CAPES).

Conflicts of Interest: The authors declare that there are no competing interests regarding the publication of this paper.

$\begin{array}{ll}\text { Abbreviations } \\ \text { 4-OH-E2 } & \text { 4-Hydroxy-Estradiol } \\ \text { 8-OH-dG } & \text { 8-Hydroxy-2'-deoxyguanosine } \\ \text { 18SRNA } & \text { 18S ribosomal Ribonucleic Acid } \\ \text { AChE } & \text { 8-OH-dG-Acetylcholinesterase } \\ \text { ATP } & \text { Adenosine triphosphate } \\ \text { AKT1 } & \text { Other denomination of protein kinase B (PKB) type } 1 \\ \text { AKT2 } & \text { Other denomination of protein kinase B (PKB) type } 2 \\ \text { ANOVA } & \text { Analysis of variance } \\ \text { BpV-pic } & \text { Bisperoxovanadium-pic }\end{array}$


BRAF B-Raf proto-Oncogene, Serine/Threonine Kinase

3-BTA (E)-benzhydryl 3-(3,4,5-trimethoxyphenyl)acrylate

CT Cycle Threshold

DMSO Dimethyl sulfoxide

cDNA Complementary Deoxyribonucleic Acid

DVL1 Dishevelled type 1

EGF Epidermal Growth Factor

EGFR Epidermal Growth Factor Receptor

FBS Fetal Bovine Serum

FPG Fluorescence Plus Giemsa

ER Endoplasmic Reticulum

FOS Finkel Osteosarcoma

GBM Glioblastoma

HGG High-Grade Glioma

HHV Human Herpes virus

$\mathrm{IC}_{50}$ The half maximal inhibitory concentration

IGF-1 Insulin-like Growth Factor-1

KRAS Kirsten Rat Sarcoma viral oncogene homolog

LDH Lactate Dehydrogenase

MMC Mitomycin C

MTT 3-(4,5-Dimethylthiazol-2-yl)-2,5-diphenyltetrazolium bromide

NC Negative Control

NFkB Necrosis Factor kappa B

NFkB1 Necrosis Factor kappa B1

NFkB1A Necrosis Factor kappa B inhibitor- $\alpha$

NFkB2 Necrosis Factor kappa B2

PBS Phosphate-buffered saline

PC Positive control

PCR Polymerase Chain Reaction

PHWB Peripheral Human Whole Blood

PPL Piplartine

PTEN Phosphatase and Tensin Homolog

PIP3K Phosphatidylinositol-4,5-bisphosphate 3-kinase

PIK3CA Phosphatidylinositol-4,5-bisphosphate 3-kinase catalytic

PIK3R1 Phosphatidylinositol-3-kinase regulatory subunit 1

PRDX4 Peroxiredoxin 4

RAF1 Rapidly Accelerated Fibrosarcoma type 1

ROS Reactive Oxygen Species

RT Radiotherapy

RT-PCR Real Time-Polymerase Chain Reaction

SAR Structure Activity Relationship

SCE Sister Chromatid Exchange

SH-SY5Y Human Neuroblastoma cell model

SV40 Simian Vacuolating virus 40

TAC Total Antioxidant Capacity

TAS Total Antioxidant Status

TMZ Temozolomide

TOS Total Oxidant Status

TP53 Tumor Protein p53

\section{References}

1. Ohgaki, H.; Kleihues, P. Population-based studies on incidence, survival rates, and genetic alterations in astrocytic and oligodendroglialgliomas. J. Neuropathol. Exp. Neurol. 2005, 64, 479-489. [CrossRef] [PubMed] 
2. Gallego, O. Nonsurgical treatment of recurrent glioblastoma. Curr. Oncol. 2015, 22, 273. [CrossRef] [PubMed]

3. Zheng, T.; Cantor, K.P.; Zhang, Y.; Chiu, B.C.; Lynch, C.F. Risk of brain glioma not associated with cigarette smoking or use of other tobacco products in Iowa. Cancer Epidemiol. Biomark. Prev. 2001, 10, 413-414.

4. Huncharek, M.; Kupelnick, B.; Wheeler, L. Dietary cured meat and the risk of adult glioma: A meta-analysis of nine observational studies. J. Environ. Pathol. Toxicol. Oncol. 2003, 22. [CrossRef]

5. Hardell, L.; Carlberg, M.; Mild, K.H. Epidemiological evidence for an association between use of wireless phones and tumor diseases. Pathophysiology 2009, 16, 113-122. [CrossRef] [PubMed]

6. Vilchez, R.A.; Kozinetz, C.A.; Arrington, A.S.; Madden, C.R.; Butel, J.S. Simian virus 40 in human cancers. Am. J. Med. 2003, 114, 675-684. [CrossRef]

7. Chi, J.; Gu, B.; Zhang, C.; Peng, G.; Zhou, F.; Chen, Y.; Wang, J. Human herpesvirus 6 latent infection in patients with glioma. J. Infect. Dis. 2012, 206, 1394-1398. [CrossRef] [PubMed]

8. Salazar-Ramiro, A.; Ramírez-Ortega, D.; Pérez de la Cruz, V.; Hérnandez-Pedro, N.Y.; GonzálezEsquivel, D.F.; Sotelo, J.; Pineda, B. Role of redox status in development of glioblastoma. Front. Immunol. 2016, 7, 156. [CrossRef] [PubMed]

9. Rinaldi, M.; Caffo, M.; Minutoli, L.; Marini, H.; Abbritti, R.V.; Squadrito, F.; Trichilo, V.; Valenti, A.; Barresi, V.; Altavilla, D.; et al. ROS and brain gliomas: An overview of potential and innovative therapeutic strategies. Int. J. Mol. Sci. 2016, 17, 984. [CrossRef] [PubMed]

10. Kim, T.H.; Song, J.; Kim, S.H.; Parikh, A.K.; Mo, X.; Palanichamy, K.; Kaur, B.; Yu, J.; Yoon, S.O.; Nakano, I.; et al. Piperlongumine treatment inactivates peroxiredoxin 4, exacerbates endoplasmic reticulum stress, and preferentially kills high-grade glioma cells. Neuro Oncol. 2014, 16, 1354-1364. [CrossRef] [PubMed]

11. Bezerra, D.P.; Pessoa, C.; De Moraes, M.O.; Saker-Neto, N.; Silveira, E.R.; Costa-Lotufo, L.V. Overview of the therapeutic potential of piplartine (piperlongumine). Eur. J. Pharm. Sci. 2013, 48, 453-463. [CrossRef] [PubMed]

12. Burci, L.M.; Pereira, I.T.; Silva, L.M.D.; Rodrigues, R.V.; Facundo, V.A.; Militao, J.S.L.T.; Santos, A.R.S.; Marques, M.C.A.; Baggio, C.H.; Werner, M.F.D.P. Antiulcer and gastric antisecretary effects of dichlomethane fraction and piplartine obtained from fruits of Piper tuberculatum Jacq. In rats. J. Ethnopharmacol. 2013, 148, 165-174. [CrossRef] [PubMed]

13. Son, D.J.; Kim, S.Y.; Han, S.S.; Kim, C.W.; Kumar, S.; Park, B.S.; Lee, S.E.; Yun, Y.P.; Jo, H.; Park, Y.H. Piperlongumine inhibits atherosclerotic plaque formation and vascular smooth muscle cell proliferation by suppressing PDGF receptor signaling. Biochem. Biophys. Res. Commun. 2012, 427, 349-354. [CrossRef] [PubMed]

14. Wang, Y.; Wang, J.; Li, J.; Zhang, Y.; Huang, W.; Zuo, J.; Liu, H.; Xie, D.; Zhu, P. Design, Synthesis and Pharmacological Evaluation of Novel Piperlongumine derivatives as Potential Antiplatelet Aggregation Candidate. Chem. Biol. Drug Des. 2016, 87, 833-840. [CrossRef] [PubMed]

15. Gong, L.H.; Chen, X.X.; Wang, H. Piperlongumine induces apoptosis and synergizes with cisplatin or paclitaxel in human ovarian cancer cells. Oxid. Med. Cell. Longev. 2014, 2014, 906804. [CrossRef] [PubMed]

16. Bezerra, D.P.; Militao, G.C.; de Castro, F.O.; Pessoa, C.; de Moraes, M.O.; Silveira, E.R.; Lima, M.A.S.; Elmiro, F.J.M.; Costa-Lotufo, L.V. Piplartine induces inhibition of leukemia cell proliferation triggering both apoptosis and necrosis pathways. Toxicol. In Vitro 2007, 21, 1-8. [CrossRef] [PubMed]

17. Barreiro, E.J.; Kümmerle, A.E.; Fraga, C.A. The methylation effect in medicinal chemistry. Chem. Rev. 2011, 111, 5215-5246. [CrossRef] [PubMed]

18. Müller, G.; Albers, M.; Fischer, R.; Hebler, G.; Lehmann, T.E.; Okigami, H.; Tajimi, M.; Bacon, K.; Rölle, T. Discovery and evaluation of piperidinyl carboxylic acid derivatives as potent $\alpha 4 \beta 1$ integrin antagonists. Bioorg. Med. Chem. Lett. 2001, 11, 3019-3021. [CrossRef]

19. Hernandes, M.Z.; Cavalcanti, S.M.T.; Moreira, D.R.M.; de Azevedo, J.; Filgueira, W.; Leite, A.C.L. Halogen atoms in the modern medicinal chemistry: Hints for the drug design. Curr. Drug Targets 2010, 11, 303-314. [CrossRef] [PubMed]

20. Thomas, G. Fundamentals of Medicinal Chemistry; John Wiley \& Sons Ltd.: Chichester, UK, 2009.

21. Capello, T.M.; Martins, E.G.; De Farias, C.F.; Figueiredo, C.R.; Matsuo, A.L.; Passero, L.F.; Oliveira-Silva, D.; Sartorelli, P.; Lago, J.H. Chemical composition and in vitro cytotoxic and antileishmanial activities of extract and essential oil from leaves of Piper cernuum. Nat. Prod. Commun. 2015, 10, 285-288. [PubMed]

22. Morgan, M.J.; Liu, Z.G. Crosstalk of reactive oxygen species and NF-kB signaling. Cell. Res. 2011, 21, 103. [CrossRef] [PubMed] 
23. Clark, M.J.; Homer, N.; O'connor, B.D.; Chen, Z.; Eskin, A.; Lee, H.; Merriman, B.; Nelson, S.F. U87MG decoded: The genomic sequence of a cytogenetically aberrant human cancer cell line. PLoS Genet. 2010, 6, e1000832. [CrossRef] [PubMed]

24. Jin, H.O.; Park, J.A.; Kim, H.A.; Chang, Y.H.; Hong, Y.J.; Park, I.C.; Lee, J.K. Piperlongumine downregulates the expression of HER family in breast cancer cells. Biochem. Biophys. Res. Commun. 2017, 486, 1083-1089. [CrossRef] [PubMed]

25. Song, B.; Zhan, H.; Bian, Q.; Gu, J. Piperlongumine inhibits gastric cancer cells via suppression of the JAK1, 2/STAT3 signaling pathway. Mol. Med. Rep. 2016, 13, 4475-4480. [CrossRef] [PubMed]

26. Golovine, K.; Makhov, P.; Naito, S.; Raiyani, H.; Tomaszewski, J.; Mehrazin, R.; Tulin, A.; Kutikov, A.; Uzzo, R.G.; Kolenko, V.M. Piperlongumine and its analogs down-regulate expression of c-Met in renal cell carcinoma. Cancer Biol. Ther. 2015, 16, 743-749. [CrossRef] [PubMed]

27. Meegan, M.J.; Nathwani, S.; Twamley, B.; Zisterer, D.M.; O’Boyle, N.M. Piperlongumine (piplartine) and analogues: Antiproliferative microtubule-destabilising agents. Eur. J. Med. Chem. 2017, 125, 453-463. [CrossRef] [PubMed]

28. Kong, E.; Kim, Y.; Kim, Y.; Cho, H.; Yu, S.; Kim, K.; Chang, J.; Ahn, S. Piplartine induces caspase-mediated apoptosis in PC-3 human prostate cancer cells. Oncol. Rep. 2008, 20, 785-792. [PubMed]

29. Bezerra, D.P.; Ferreira, P.M.; Machado, C.M.; de Aquino, N.C.; Silveira, E.R.; Chammas, R.; Pessoa, C. Antitumour efficacy of Piper tuberculatum and piplartine based on the hollow fiber assay. Planta Med. 2015, 81, 15-19. [CrossRef] [PubMed]

30. Voce, D.J.; Schmitt, A.M.; Uppal, A.; McNerney, M.E.; Bernal, G.M.; Cahill, K.E.; Wahlstrom, J.S.; Nassiri, A.; $\mathrm{Yu}, \mathrm{X}$; Crawley, C.D.; et al. Nfkb1 is a haploinsufficient DNA damage-specific tumor suppressor. Oncogene 2015, 34, 2807-2813. [CrossRef] [PubMed]

31. Nagai, S.; Washiyama, K.; Kurimoto, M.; Takaku, A.; Endo, S.; Kumanishi, T. Aberrant nuclear factor- $\mathrm{kB}$ activity and its participation in the growth of human malignant astrocytoma. J. Neurosurg. Pediatr. 2002, 96, 909-917. [CrossRef] [PubMed]

32. Raychaudhuri, B.; Han, Y.; Lu, T.; Vogelbaum, M.A. Aberrant constitutive activation of nuclear factor $\mathrm{kB}$ in glioblastoma multiforme drives invasive phenotype. J. Neurooncol. 2007, 85, 39-47. [CrossRef] [PubMed]

33. Nadiminty, N.; Lou, W.; Sun, M.; Chen, J.; Yue, J.; Kung, H.J.; Evans, C.P.; Zhou, Q.; Gao, A.C. Aberrant activation of the androgen receptor by NF-kappaB2/p52 in prostate câncer cells. Cancer Res. 2010, 70, 3309-3319. [CrossRef] [PubMed]

34. Ruan, D.; Li, X.; Li, A.; Liu, B.; Xu, F. Paclitaxel inhibits growth and proliferation of glioblastoma through MMP-9-meidated p38/JNK signaling pathway. Biomed. Res. 2017, 28, 7348-7353.

35. Tseng, S.H.; Bobola, M.S.; Berger, M.S.; Silber, J.R. Characterization of paclitaxel (Taxol $\left.{ }^{\circledR}\right)$ sensitivity in human glioma- and medulloblastoma-derived cell lines. Neuro Oncol. 1999, 1, 101-108. [CrossRef] [PubMed]

36. Li, X.J.; Deng, L.; Brandt, S.L.; Goodwin, C.B.; Ma, P.; Yang, Z.; Mali, R.S.; Liu, Z.; Kapur, R.; Serezani, C.H.; et al. Role of $\mathrm{p} 85 \alpha$ in neutrophil extra- and intracelular reactive oxygen species generation. Oncotarget 2016, 7, 23096-23105. [PubMed]

37. Parsons, D.W.; Jones, S.; Zhang, X.; Lin, J.C.; Leary, R.J.; Angenendt, P.; Mankoo, P.; Carter, H.; Siu, I.M.; Gallia, G.L.; et al. An Integrated Genomic Analysis of Human Glioblastoma Multiforme. Science 2008, 321, 1807-1812. [CrossRef] [PubMed]

38. Rao, S.K.; Edwards, J.; Joshi, A.D.; Siu, I.M.; Riggins, G.J. A survey of glioblastoma genomic amplifications and deletions. J. Neurooncol. 2010, 96, 169-179. [CrossRef] [PubMed]

39. Liu, X.Y.; Zhang, L.J.; Chen, Z.; Liu, L.B. The PTEN inhibitor bpV (pic) promotes neuroprotection against amyloid $\beta$-peptide (25-35)-induced oxidative stress and neurotoxicity. Neurol. Res. 2017, 39, 758-765. [CrossRef] [PubMed]

40. Duan, S.; Yuan, G.; Liu, X.; Ren, R.; Li, J.; Zhang, W.; Wu, J.; Xu, X.; Fu, L.; Li, Y.; et al. PTEN deficiency reprogrammes human neural stem cells towards a glioblastoma stem cell-like phenotype. Nat. Commun. 2015, 6, 1-14. [CrossRef] [PubMed]

41. Pollack, I.F.; Hamilton, R.L.; Finkelstein, S.D.; Campbell, J.W.; Martinez, A.J.; Sherwin, R.N.; Bozik, M.E.; Gollin, S.M. The relationship between TP53 mutations and overexpression of p53 and prognosis in malignant gliomas of childhood. Cancer Res. 1997, 57, 304-309. [PubMed] 
42. Robinson, J.P.; VanBrocklin, M.W.; Guilbeault, A.R.; Signorelli, D.L.; Brandner, S.; Holmen, S.L. Activated BRAF induces gliomas in mice when combined with Ink4a/Arf loss or Akt activation. Oncogene 2010, 29, 335. [CrossRef] [PubMed]

43. Jin, S.Y.; Lee, H.S.; Kim, E.K.; Ha, J.M.; Kim, Y.W.; Bae, S. Reactive oxygen species and PI3K/Akt signaling in cancer. Free Radic. Biol. Med. 2014, 75, S34-S35. [CrossRef] [PubMed]

44. Okoh, V.O.; Felty, Q.; Parkash, J.; Poppiti, R.; Roy, D. Reactive oxygen species via redox signaling to $\mathrm{PI} 3 \mathrm{~K} / \mathrm{AKT}$ pathway contribute to the malignant growth of 4-hydroxy estradiol-transformed mammary epithelial cells. PLoS ONE 2013, 8, e54206. [CrossRef] [PubMed]

45. Haas-Kogan, D.; Shalev, N.; Wong, M.; Mills, G.; Yount, G.; Stokoe, D. Protein kinase B (PKB/Akt) activity is elevated in glioblastoma cells due to mutation of the tumor suppressor PTEN/MMAC. Curr. Biol. 1998, 8, 1195-1998. [CrossRef]

46. Holland, E.C.; Celestino, J.; Dai, C.; Schaefer, L.; Sawaya, R.E.; Fuller, G.N. Combined activation of Ras and Akt in neural progenitors induces glioblastoma formation in mice. Nat. Genet. 2000, 25, 55. [CrossRef] [PubMed]

47. Xu, J.H.; Hu, S.L.; Shen, G.D.; Shen, G. Tumor suppressor genes and their underlying interactions in paclitaxel resistance in cancer therapy. Cancer Cell Int. 2016, 16, 13. [CrossRef] [PubMed]

48. Błasiak, J.; Gloc, E.; Warszawski, M. A comparison of the in vitro genotoxicity of anticancer drugs idarubicin and mitoxantrone. Acta Biochim. Pol. 2002, 49, 145-155. [PubMed]

49. Turkez, H.; Tatar, A.; Hacimuftuoglu, A.; Ozdemir, E. Boric acid as a protector against paclitaxel genotoxicity. Acta Biochim. Pol. 2010, 57, 95-97. [PubMed]

50. Steverding, D.; da Nóbrega, F.R.; Rushworth, S.A.; de Sousa, D.P. Trypanocidal and cysteine protease inhibitory activity of isopentylcaffeate is not linked in Trypanosomabrucei. J. Parasitol. Res. 2016, 115, 4397-4403. [CrossRef] [PubMed]

51. Peterson, J.R.; Russell, M.E.; Surjasasmita, I.B. Synthesis and experimental ionization energies of certain (E)-3-arylpropenoic acids and their methyl esters. J. Chem. Eng. 1988, 33, 534-537. [CrossRef]

52. Jung, J.C.; Moon, S.; Min, D.; Park, W.K.; Jung, M.; Oh, S. Synthesis and Evaluation of a Series of 3,4,5-Trimethoxycinnamic Acid Derivatives as Potential Antinarcotic Agents. Chem. Biol. Drug Des. 2013, 81, 389-398. [CrossRef] [PubMed]

53. Kumar, S.; Arya, P.; Mukherjee, C.; Singh, B.K.; Singh, N.; Parmar, V.S.; Prasad, A.K.; Ghosh, B. Novel aromatic ester from Piper longum and its analogues inhibit expression of cell adhesion molecules on endothelial cells. Biochemistry 2005, 44, 15944-15952. [CrossRef] [PubMed]

54. Hayat, S.; Choudhary, M.I.; Khan, K.M.; Abbaskhan, A. Two new cinnamic acid esters from marine brown alga Spatoglossum variabile. Chem. Pharm. Bull. 2002, 50, 1297-1299. [CrossRef] [PubMed]

55. Kumar, S.; Singh, B.K.; Arya, P.; Malhotra, S.; Thimmulappa, R.; Prasad, A.K.; Van der Eycken, E.; Olsen, C.E.; Depass, A.L.; Biswal, S.; et al. Novel natural product-based cinnamates and their thio and thiono analogs as potent inhibitors of cell adhesion molecules on human endothelial cells. Eur. J. Med. Chem 2011, 46, 5498-5511. [CrossRef] [PubMed]

56. Li, W.; Li, N.; Tang, Y.; Li, B.; Liu, L.; Zhang, X.; Fu, H.; Duan, J.A. Biological activity evaluation and structure-activity relationships analysis of ferulic acid and caffeic acid derivatives for anticancer. Bioorg. Med. Chem. Lett. 2012, 22, 6085-6088. [CrossRef] [PubMed]

57. Vogel, A.I.; Tatchell, A.R.; Furniss, B.S.; Hannaford, A.S.; Smith, P.W.G. Textobook of Pratical Organic Chemistry; Longman Scientific \& Technical: Essex, UK, 1989.

58. Itoh, K.; Utsukihara, T.; Funayama, K.; Sakamaki, H.; Kanamori, M.; Takahashi, T.T.; Saitoh, Y.; Matsushita, M.; He, L.; Hashimoto, C.; et al. Reaction of $\alpha, \beta$-unsaturated ketones using cerium (IV) sulfate tetrahydrate in acetic acid, applied organometallic chemistry appl. Organomet. Chem. 2007, 21, 1029-1032. [CrossRef]

59. Magens, S.; Ertelt, M.; Jatsch, A.; Plietker, B. A nucleophilic Fe catalyst for transesterifications under neutral conditions. Org. Lett. 2008, 10, 53-56. [CrossRef] [PubMed]

60. Rajan, P.; Vedernikova, I.; Cos, P.; Berghe, D.V.; Augustyns, K.; Haemers, A. Synthesis and evaluation of caffeic acid amides as antioxidants. Bioorg. Med. Chem. Lett. 2001, 11, 215-217. [CrossRef]

61. Nomura, E.; Hosoda, A.; Mori, H.; Taniguchi, H. Rapid base-catalyzed decarboxylation and amide-forming reaction of substituted cinnamic acids via microwave heating. Green Chem. 2005, 7, 863-866. [CrossRef] 
62. Nordstrom, L.U.; Vogt, H.; Madsen, R. Silica gel mediated amide bond formation: An environmentally benign method for liquid-phase synthesis and cytotoxic activities of amides. J. Am. Chem. Soc. 2008, 30, 17672-17673.

63. Leslie, B.J.; Holaday, C.R.; Nguyen, T.; Hergenrother, P.J. Phenylcinnamides as novel antimicotic agents. J. Med. Chem. 2010, 53, 3964-3972. [CrossRef] [PubMed]

64. Ghosh, S.C.; Li, C.C.; Chun, Z.H.; Ngiam, J.S.Y.; Seayad, A.M.; Chen, A. Mesoporous Niobium Oxide Spheres as an Effective Catalyst for the Transamidation of Primary Amides with Amines. Adv. Synth. Catal. 2014, 356, 475-484. [CrossRef]

65. Yang, X.-D.; Zeng, X.-H.; Zhao, Y.-H.; Wang, X.-Q.; Pan, Z.-Q.; Li, L.; Zhang, H.-B. Silica gel mediated amide bond formation: An environmentally benign method for liquid-phase synthesis and cytotoxic activities of amides. J. Comb. Chem. 2010, 12, 307-310. [CrossRef] [PubMed]

66. Cacciatore, I.; Fornasari, E.; Marinelli, L.; Eusepi, P.; Ciulla, M.; Ozdemir, O.; Tatar, A.; Turkez, H.; Di Stefano, A. Memantine-derived drugs as potential antitumor agents for the treatment of glioblastoma. Eur. J. Pharm. Sci. 2017, 109, 402-411. [CrossRef] [PubMed]

67. Togar, B.; Turkez, H.; Hacimuftuoglu, A.; Tatar, A.; Geyikoglu, F. Guaiazulene biochemical activity and cytotoxic and genotoxic effects on rat neuron and N2a neuroblastom cells. J. Intercult. Ethnopharmacol. 2015, 4, 29. [CrossRef] [PubMed]

68. Turkez, H.; Togar, B.; Di Stefano, A.; Taspınar, N.; Sozio, P. Protective effects of cyclosativene on $\mathrm{H}_{2} \mathrm{O}_{2}$-induced injury in cultured rat primary cerebral cortex cells. Cytotechnology 2015, 67, 299-309. [CrossRef] [PubMed]

69. Evans, H.J.; O'Riordan, M.L. Human peripheral blood lymphocytes for the analysis of chromosome aberrations in mutagen tests. Mutat. Res. Genet. Toxicol. Environ. Mutagen. 1975, 31, 135-148. [CrossRef]

70. Abdel-Wahab, B.A.; Metwally, M.E. Ginkgo biloba enhances the anticonvulsant and neuroprotective effects of sodium valproate against kainic acid-induced seizures in mice. J. Pharmacol. Toxicol. 2011, 6, 679-690. [CrossRef]

Sample Availability: Samples of the compounds not are available from the authors.

(C) 2018 by the authors. Licensee MDPI, Basel, Switzerland. This article is an open access article distributed under the terms and conditions of the Creative Commons Attribution (CC BY) license (http:// creativecommons.org/licenses/by/4.0/). 